\title{
THE DYNAMICS OF PRIVATELY HELD BUSINESS ASSETS \\ IN THE UNITED STATES
}

\author{
Kim Pernell \\ University of Toronto
}

Geoffrey T. Wodtke

University of Chicago

January 6, 2022

Keywords: business, wealth, capital, inequality, financialization

Corresponding Author: Kim Pernell, University of Toronto, Department of Sociology, 725 Spadina Avenue, Toronto, ON M5S 2J4, Canada. Email: kim.pernell.gallagher@utoronto.ca

Acknowledgements: We thank Laura Adler, Anne Bowers, Santiago Campero, Clayton Childress, Stefan Dimitriades, Laura Doering, Alicia Eads, Angelina Grigoryeva, Barbara Kiviat, Carly Knight, Sida Liu, Robert Manduca, Jared Schachner, Ross Stolzenberg, Andras Tilcsik, Xiang Zhou, and the Toronto Group of Seven for helpful comments on previous iterations of this project. We thank Richard Kennedy for assistance with data collection. This research was supported by the Canada Research Chair program. 


\begin{abstract}
Although privately held businesses are central to the American economy, little is known about how their assets are distributed among the population. In this study, we describe the household distribution of private business assets in the United States and examine how it has changed over time. Using data from the 1989-2019 Survey of Consumer Finances, we show that the relative number of business owners has remained stagnant at low levels and that assets in privately held firms have become increasingly concentrated among the wealthiest owners over time. At the most recent wave of data collection, the top $1 \%$ of households controlled nearly $80 \%$ of private business assets, up from about $70 \%$ in the late 1980 s. We attempt to explain this trend by evaluating how technological change, the financialization of banking, and rising market power have influenced the distribution of private business assets in recent decades. Our findings suggest that all three factors contributed to increasing asset concentration in this sector.
\end{abstract}


Privately held businesses, which include sole proprietorships, partnerships, and corporations without publicly traded ownership shares, once captured considerable attention from classical sociologists. In volume three of Capital, Marx (1993 [1894]) places the distinct dynamics of privately held businesses (what he calls "individual capitals," "owner-managers," "functioning capitalists") and the early precursors to the modern publicly traded corporation ("stock companies," "money capitalists") front and center. Competition among "individual capitals" and their conglomeration into ever larger joint-stock companies, along with conflict between their owners and workers, were all key elements in Marx's theory of capitalist development and succession by socialism. Similarly, Weber (2003 [1889]), in The History of Commercial Partnerships, carefully noted distinctions among firms in early market economies, including proprietorships, partnerships, and corporations, and attended to the institutional conditions that support different organizational forms and financing arrangements (see also Ruef and Lounsbury 2007).

Privately held businesses continue to play a central role in the modern U.S. economy. Although large publicly traded companies, like Alphabet Inc. or Walmart Inc., attract the vast majority of public and scholarly attention, over 99 percent of U.S. firms in operation today are privately held (Asker et al. 2011). These businesses produce the majority of the country's economic output, and they are also top employers, generating over $60 \%$ of new job growth (Small Business Association 2012; U.S. Bureau of Labor Statistics 2020). Moreover, emerging evidence points to a possible link between private business ownership and economic trends like rising income inequality (Smith et al. 2019; Wodtke 2016), with tax records indicating that private business earnings account for nearly all of the growth in the income share of the top $1 \%$ over the past two decades (Smith et al. 2019). 
Despite the importance of privately held businesses in the modern economy, and despite a clear theoretical precedent for viewing them as objects of sociological study, these firms and their owners have received surprisingly little attention in contemporary research on the economy, organizations, and social stratification. In 1986, Curran and Burrows (1986: 265) lamented that the volume of sociological research on privately held businesses was vastly incommensurate with their "economic, social, and ideological significance." Over thirty years later, little has changed. Publicly traded corporations continue to command the vast preponderance of scholarly interest in economic sociology (e.g. Davis 2009; Dobbin and Zorn 2005; Mizruchi 2004), while stratification research focuses more on inequalities that stem from intangible forms of capital, including skills, social connections, and cultural knowledge (e.g. Hout 2012; Lin 1999; Lareau 2003). Even within the growing literature on wealth inequality, the focus has been on composite measures of net worth, homeownership, or financial assets, not capital in private businesses (Killewald et al. 2017). As a result, sociological scholarship has been largely silent on the key questions of how resources within the privately held business sector are distributed, whether these patterns have changed over time, and why. The present study bridges this gap in our knowledge by making creative use of the Survey of Consumer Finances (SCF) to examine the distribution of private business assets among U.S. households from 1989 to 2019.

The privately held business sector is often depicted as relatively accessible and diffuse, comprising many small, independent businesses with a comparatively equitable distribution of assets. In other words, these are the family businesses on Main Street, which act as important foils to the political and economic dominance of corporate giants on Wall Street (Lee 2010; Mitchell and Holmberg 2020; Shane 2013). This popular view of the sector has encouraged scholars, journalists, and policymakers alike to conceptualize private business ownership as a 
"building block of economic opportunity...for many families below the very top in income and wealth" (Yellen 2014), "an important channel for inclusion, poverty reduction, and mobility" (Talbot 2018), and "a powerful antidote to inequality" (Means 2016).

Yet there are also compelling reasons to suspect that this sector might not be such a powerful antidote to economic concentration. Many of the factors known to influence selection into business ownership and firm success, like access to financing, skills, and information, are quite unequally distributed themselves (Cooper et al. 1994; Fairlie and Robb 2007; Levine and Rubinstein 2017), as are several likely correlates of business valuations, like net earnings and employment growth (U.S. Bureau of Labor Statistics 2020; Smith et al. 2019). Privately held businesses have also been exposed to many of the same economic transformations shown to promote rising inequality elsewhere in the economy, including technological changes that reward non-routine skills (Autor et al. 2003, 2006; Bound and Johnson 1992), the financialization of banking (Krippner 2011; Lin and Neely 2020), and the consolidation of market power across industries (Autor et al. 2017; Azar et al. 2020; Tomaskovic-Devey and Avent Holt 2019). Because the distribution of privately held business assets has attracted so little scholarly attention, extant research offers little in the way of clear predictions for the form or trend this distribution will take. However, these considerations raise the possibility that this asset distribution might be highly, and perhaps increasingly, concentrated.

Consistent with this view, our analysis of the SCF indicates that privately held business assets are currently one of the most unequally distributed forms of capital in the U.S. economy. Few households own any appreciable equity in a private business, and even among those that do, a small fraction of top owners control the vast majority of assets in the sector. We also find that the distribution of privately held business assets has grown even more concentrated among the 
wealthiest owners over time. At the most recent wave of data collection, we estimate that the top $1 \%$ of households control nearly $80 \%$ of privately held business assets, up from about $70 \%$ in the late 1980s. By comparison, the top 1\% share of financial assets (e.g., bond-holdings and stock in publicly traded firms) remained below $40 \%$ throughout the same period. This pattern suggests that assets ostensibly parked on Main Street may actually be distributed far more unequally than those that currently trade on Wall Street. Finally, after evaluating potential contributors to the trend of rising asset concentration in the private business sector, we find evidence implicating increasing returns to owner skills, changing patterns of credit access, and diverging valuations for larger versus smaller firms.

In the sections that follow, we begin by reviewing the little that is known about privately held businesses and their ownership in the United States. Then, we discuss three major economic transformations that may have influenced the distribution of private business assets in recent decades, focusing on the uneven impact of technological change, the effects of shifting bank strategy in the modern financialized era, and rising market power. After outlining our approach to measuring the value of equity in privately held firms using the SCF, we describe our strategy for modeling its distribution among U.S. households and present estimates that explain how this distribution has changed over time. We conclude by discussing implications for scholarship in social stratification and economic sociology.

\section{THE DISTRIBUTION OF PRIVATELY HELD BUSINESS ASSETS}

We conceptualize the accumulation of privately held business assets as governed by two processes: first, selection into or out of ownership of a private firm, and second, the market valuation of that firm. The selection process involves the decision to start or acquire a private 
firm, the inheritance of a family enterprise, a business failure, or divestment (e.g., selling the business, becoming a target of an acquisition, or issuing an initial public offering). The valuation process, which is contingent on selection into ownership, involves market assignment of monetary value to an equity stake in a firm.

Most existing studies of these selection and valuation processes are found in the literature on entrepreneurship (e.g. Ruef and Lounsbury 2007; Thornton et al. 2011). Although findings from studies that focus on only a fraction of privately held businesses-entrepreneurial ventures - are unlikely to generalize, they do provide a useful starting point for our own investigation. Extant research on entrepreneurship finds that individual characteristics, including skills, access to information and capital, demographics, and traits like risk tolerance, motivation, and locus of control, can influence both selection into business ownership and business performance (e.g. Cooper et al. 1994; Fairlie and Robb 2007; Kihlstrom and Laffont 1979; Lazear 2005; Levine and Rubenstein 2017; Rubinstein and Ross 2020). Similarly, institutional and contextual factors, including the relative availability of technology, local norms, regional differences in population structure, social network relationships, and features of legal, industry, and regulatory environments, are also shown to matter (e.g. Aldrich 2007; Greve and Salaff 2003; Ruef and Lounsbury 2007; Stigler 1983).

For several reasons, we suspect these findings are compatible with a pattern of relatively extreme concentration in the contemporary distribution of privately held business assets. First, building on research that finds that individual access to capital, information, and skills predicts selection into business ownership and firm performance (Cooper et al. 1994; Fairlie and Robb 2007; Lazear 2005), we underscore how unevenly distributed these vital inputs are. Profound constraints on the ability to start a business and steward it to success could substantially limit 
participation in the sector, favoring asset concentration. Second, building on research that shows that many industries feature considerable barriers to entry, due to the capital intensity of production, economies of scale, regulatory obstacles, or predatory pricing (Stigler 1983;

Tomaskovic-Devey and Avent Holt 2019), we underscore how these conditions might inhibit the entry and growth of newer or smaller privately held businesses, again favoring concentration. Finally, building on research that finds that several likely correlates of business valuations, including net earnings, profit rates, and employment growth, are themselves highly concentrated (Fairlie and Robb 2007; U.S. Bureau of Labor Statistics 2020; Smith et al. 2019), we expect similar patterns to characterize the distribution of equity in privately held firms.

\section{TRENDS IN THE DISTRIBUTION OF PRIVATELY HELD BUSINESS ASSETS}

We also expect that the distribution of privately held business assets has grown more concentrated over time. Management scholars and financial journalists have long held that the rise of new innovations, like peer-to-peer lending, e-commerce, or open source product platforms, have democratized the privately held business sector by broadening access to the capital, skills, or networks needed to enter and excel in it (Mills 2019; Wolf 2012). If these new technologies made it easier for small-scale entrepreneurs to reach consumers or access capital, it is reasonable to expect the distribution of private business assets to grow less concentrated over time. However, the emergence of "disruptive" financial and technological innovation was only one of multiple transformations that unfolded within the U.S. economy over the past several decades. Other transformations, we argue, may have had a very different impact on distributional dynamics. 
Specifically, we highlight three economic transformations that have been shown to contribute to rising inequality in other domains. These include (i) the rapid growth of computing, communication, and automation technologies that are labor-saving and favor non-routine cognitive or communication skills (Autor et al. 2003, 2006; Bound and Johnson 1992); (ii) the changes in bank strategy that accompanied the turn to financialization (Lin and Neely 2020; Pernell 2020); and (iii) the increase in the market power of large established firms, which has been observed across many industries (Autor et al. 2017; Azar et al. 2020; De Loecker et al. 2020; Grullon et al. 2019). In what follows, we discuss each transformation and its potential implications for trends in the distribution of privately held business assets.

\subsection{Technological Change}

The introduction of graphical-interface operating systems in the late 1980s led to the explosive growth and widespread adoption of computers throughout the economy. The backbone of the modern internet was also established in this period, and restrictions on its commercial use were lifted in the early 1990s. Other advances in information processing, communications, robotics, and automation followed. We posit that these technological changes may have influenced the distribution of privately held business assets through three mechanisms: capital-labor substitution, capital-skill complementarity, and skill-biased adaptation.

Capital-labor substitution refers to the process by which the physical means of production replace human effort within the production process. Technological improvements in computing, telecommunications, and automation have increasingly allowed firms to substitute capital for labor in many different industries (Acemoglu and Restrepo 2017; Brynjolfsson and McAfee 2011; Graetz and Michaels 2018), which raised both the capital intensity of production and the 
rate of return on capital (Piketty 2014). Although rising rates of return and increasing capital intensity are not inherently disequalizing, they may push levels of concentration higher when assets in the private business sector are unequally distributed to begin with. In this situation, technological changes that elevate rates of return and intensify the use of capital are likely to increase asset concentration if high-value firms are better equipped to adopt the new technology.

Capital-skill complementarity refers to a related process by which capital substitutes for "unskilled" labor more easily than for "skilled" labor. In this situation, growing capital intensity tends to raise the relative productivity of "skilled" labor (Griliches 1969). Capital-skill complementarity is relevant to the distribution of business assets because it is partly a function of an owner's skills. Kaldor (1934), for example, emphasizes the importance of an owner's “coordinating ability" for firm survival, performance, and valuation. If advances in computing and communication technology have raised the productivity of coordinating ability or other managerial skills, these dynamics may promote asset concentration by favoring the selection and growth of firms owned by those with higher skill in these areas. Consistent with this argument, prior research finds that new forms of capital may enhance the productivity of non-routine problem solving and communication skills (Autor et al. 2003), which are central to effective coordination and management at privately held firms (Levine and Rubenstein 2017).

Skill-biased adaptation refers to the process by which individuals differentially respond to economic disruption. Highly skilled individuals may be better equipped than those with fewer skills to pivot and innovate in response to the disruptions created by technological change (Nelson and Phelps 1966; Violante 2008). This variable adaptability is thought to arise from the relative ease with which individuals at different skill levels learn to use new technology, appreciate its potential applications, and deploy it in the most productive ways. If business 
owners with more advanced skills are able to adjust, sustain, and grow their firms during periods of rapid technological change, while those with less advanced skills get left behind, this could also promote growing asset concentration.

To summarize, recent technological changes may have engendered patterns of capitallabor substitution and skill-biased adaption that promote asset concentration in the private business sector. These same technological changes have already been shown to have a large impact on labor markets, raising the wage premium for skilled workers and elevating the level of earnings inequality (Autor et al. 2003; Bound and Johnson 1992; Hout 2012). We test whether similar dynamics also contributed to the rising concentration of business assets by evaluating whether individual education — a common proxy for skill—-became more influential in the selection and valuation processes over time.

\subsection{The Financialization of Banking}

The ability of private businesses to grow depends on their access to capital (Berger and Udell 1998). Although many business owners turn to personal savings, retained earnings, or loans from people within their social networks to finance their firms, these sources of capital are often insufficient to generate growth. External funding is therefore important to the success of privately held enterprises, and credit offered by commercial banks has long served as the leading source of outside financing for these businesses (Berger and Udell 1998; Bitler et al. 2001).

The commercial banking sector underwent a major transformation after the 1980s (Lin and Neely 2020). Commercial banks had once obtained the vast majority of their revenue from traditional banking activities, like accepting deposits, issuing loans, and investing in low-risk government securities, but support for this traditional business model started to crumble in the 
face of rising profitability pressures and changing regulations (Dymski 1999). By the 1990s, a new business model that placed the maximization of shareholder wealth above all other objectives had taken hold in the sector (Dobbin and Jung 2010; Pernell 2020). Increasingly, bank executives sought to boost shareholder value by maximizing short-term earnings and cutting costs. These strategies attempted to maximize short-term profitability but also put financial market stability at risk (Lin and Neely 2020; Pernell et al. 2017; Pernell 2020). At present, we know very little about how this strategic shift has impacted banks' relationships with their traditional customers, privately held business owners included.

For multiple reasons, we expect that banks in the modern financialized era increasingly restricted loans to privately held businesses, with smaller, less-established, and lower-value businesses suffering the worst consequences of this shift. Although private business lending can be a lucrative activity for banks, it also demands a considerable outlay of resources (Mudd 2013). Historically, commercial banks responded to the challenge of lending in a sector marked by high failure rates, illiquid assets, and opaque information by engaging in "relationship lending." Under this model, banks gather a large amount of both "soft" information (qualitative impressions of the firm's future prospects or creditworthiness) and "hard" information (detailed financial accounts or records of past performance) about potential borrowers and their businesses, generally collected over the course of many interactions (Berger and Udell 2002; Strahan 2008). Because a bank's competitive advantage in relationship lending is thought to rest on a comprehensive understanding of individual borrowers, loans were generally only granted to members of the local community.

As bank executives came under increasing pressure to trim their operating margins in the 1990s, the relatively high-cost practice of relationship lending began to fall out of favor 
(Oppenheim 1997a). Relationship lending, which generated a non-standardized loan product, was also difficult to integrate with the new methods of revenue generation banks were turning to in pursuit of higher returns. Loans granted under this lending model were notoriously difficult to securitize (Nathan 1997) at a time when embracing securitization was considered increasingly vital to maximizing value for bank shareholders (Pernell 2020). These dynamics may have encouraged banks to restrict loans to privately held businesses in favor of other investment opportunities, or alternatively, to recoup the high costs of this practice by offering credit to businesses at higher (and thus less accessible) rates.

There is also evidence that many large banks started to experiment with an alternative "transactional" model of business lending after the late 1990s (Oppenheim 1997a; Oppenheim 1997b). Under this model, lending decisions are based on how borrowers score on a narrow range of standardized quantitative criteria, not their past relationship with the bank. The embrace of the transactional model allowed banks to cut costs by streamlining the loan evaluation process (Oppenheim 1997b; Peek and Rosengren 1998) and paved the way for lending in new geographic markets (Oppenheim 1997a). ${ }^{1}$ Its ascendance may have also come with distributional consequences for the privately held business sector. The owners of larger, well-established, and higher-value businesses tend to score highly on the "hard" criteria this model rewards, and likely benefitted from its rise. Owners of smaller, less-established, and lower-value businesses, by contrast, may have found it harder to secure credit.

Changes in banking industry structure likely exacerbated these trends. The U.S. banking industry became increasingly concentrated after the late 1980s and early 1990s, following the deregulation of interstate branching restrictions and several merger and acquisition waves (Dymski 1999; Lin and Neely 2020). Because larger banks devote a smaller proportion of their 
assets to small business lending (Berger, Kashyap, and Scalise 1995) and extend a greater proportion of loans to larger, older, and more financially secure businesses (Haynes, Ou, and Berney 1999), the changing structure of the banking industry may have come at the expense of declining credit access for smaller borrowers. The corresponding decline of community banks, which specialized in lending to local, smaller, and less-established businesses (Marquis and Lounsbury 2007; Narter 2009), may have produced similar effects.

In summary, if the same changes in bank strategy and structure that transformed modern financial markets also contributed to rising asset concentration in the privately held business sector, we expect to find evidence of two trends. First, the frequency with which privately held business owners access credit from banks should decline between 1989 and 2019. Second, the business valuations of owners that successfully access credit should increase over time, while valuations among owners that did not should stagnate or decline.

\subsection{Rising Market Power}

Marx (1993 [1894]) was among the first to point out a seemingly paradoxical tendency for market competition among "individual capitals" to negate itself. He observed that winners of the competitive process tend to drive out or acquire rivals, thereby increasing their size and reducing the number of competitors, and use these newfound advantages to extract wealth from, or exploit, others. We use the term market power to refer to conditions that allow for this type of exploitation (cf., Sorensen 2000; Tomaskovic-Devey and Avent-Holt 2019).

Rising market power involves three interrelated processes: consolidation, or the process by which incumbent firms eliminate or absorb existing competitors; insulation, or the process by which incumbents shield themselves with barriers that discourage the entry or growth of new 
competitors; and manipulation, or the process by which incumbents distort prices above or below competitive rates. These processes might promote asset concentration in the private business sector by eliminating or devaluing newer and smaller firms while preserving or raising the valuations of older and larger companies.

Virtually every industry in the U.S. economy has become more consolidated in recent decades (Autor et al. 2017; Grullon et al. 2019; Khan and Vaheesan 2017). In the service sector, for example, the fraction of total sales accrued by the 20 largest firms increased from about 10 percent in 1990 to about 16 percent in 2012 (Autor et al. 2017). Increasing consolidation is mainly a product of the expansion of large publicly traded corporations. But even when public firms drive consolidation, the distribution of privately held business assets may still be affected if larger private firms find it easier than smaller firms to survive and grow under the competitive pressures that accompany the expansion of a national conglomerate. For example, when a new Walmart opens, it may drive out all but the most successful local retailers (Fishman 2007). These dynamics could transform a competitive regional market inhabited by many smaller, local, and independent firms into one dominated by several massive public companies and a handful of private firms that are themselves quite large, promoting growth in asset concentration. The rise of private equity funds may have also facilitated consolidation in the private business sector by centralizing the ownership of many different private firms among a smaller number of limited partners or by taking comparatively large publicly traded firms private (Appelbaum and Batt 2014).

Incumbent firms across many industries have also become increasingly insulated from new competitors in recent decades (Baker and Salop 2015; Haltiwanger et al. 2012; Hathaway and Litan 2014). The startup rate of new firms has plummeted over the past forty years (Davis et 
al. 2007; Haltiwanger et al. 2012), and evidence suggests that heightened barriers to entry and a rise in anti-competitive practices are at least partly responsible for this trend (Hathaway and Litan 2014; Karahan et al. 2019). For example, intellectual property protections and exclusionary methods of vertical integration have proliferated, while regulators have adopted a more permissive approach to enforcement of anti-trust legislation (Baker and Salop 2015; Khan and Vaheesan 2017). Because new firms tend to be less highly valued than well-established incumbents, rising insulation may lead to growing asset concentration by inducing a shift in the age distribution of private firms away from younger companies with lower valuations toward older companies with higher valuations.

There is also evidence that price manipulation has grown more prevalent over time. Dominant firms have become more likely to engage in price markups above marginal costs on products sold to others (Barkai 2020; De Loecker et al. 2020), which results in a flow of economic rents from consumers to the manipulating firm. They have also become more likely to force price markdowns on the products or services they buy from others (Azar et al. 2020; Khan and Vaheesan 2017), allowing the manipulator to extract an implicit rent from suppliers. Although these forms of rent extraction are most common among public corporations, they are also a potentially important source of value for large private firms that dominate regional or local economies (e.g., Meijer Incorporated, H-E-B Grocery Company, and Wakefern Food Corporation), and occasionally, even national markets (e.g., Deloitte Limited, Mars Incorporated, S.C. Johnson \& Son Incorporated).

If rising consolidation, insulation, and manipulation contributed to growing asset concentration in the privately held business sector, we expect to find evidence for the following trends: (i) a shift in the relative frequency of older, higher-value firms compared to younger, 
lower-value firms and (ii) an increase in the valuations of large private firms even further above their smaller counterparts over time.

\section{METHODS}

\subsection{Data}

To investigate the distribution of privately held business assets, we use data from the 1989 to 2019 waves of the Survey of Consumer Finances (SCF; Board of Governors of the Federal Reserve System 2019). At each wave, the SCF gathers information from two separate samples:

(i) a multistage area probability sample of households with representative national coverage and (ii) a list sample drawn from income tax filings that is designed to disproportionately select wealthy households. Fielded triennially, interviews with the most financially knowledgeable member of the household typically begin in the spring shortly after most people have filed their income taxes. The SCF collects data on a wide variety of topics, including detailed information on income and wealth, access to credit and indebtedness, and basic demographics. For households that own a business, the SCF gathers information on its valuation, legal structure, and years in operation, among other characteristics. The SCF is well suited for the present study because it oversamples wealthy households, who are more likely to own private firms. This sampling strategy ensures that a large number of business-owning households are represented in the data and thus allows for more precise estimates of the distribution of private business assets. Specifically, the 1989 to 2019 cumulative sample consists of $n=53,553$ households, including more than 14,000 that report having an ownership stake in a private business. 


\subsection{Measures}

The outcome of interest in this study is the total value of privately held business assets in which a household has an ownership interest. Privately held businesses include sole proprietorships, partnerships, limited liability companies, and subchapter S corporations. They also include a smaller number of subchapter $\mathrm{C}$ corporations and foreign business entities whose stock is not traded on a public exchange. These businesses may be actively managed by members of the household, or they may represent passive investments in non-actively managed firms. ${ }^{2}$ The value of private business assets is equal to the present market value of a household's net equity in firms of this type, as estimated by the respondent, with adjustments for outstanding loans or business debts. Nominal values are adjusted for price inflation over time using the Consumer Price Index - Research Series and expressed in 2019 dollars. We censor a small number $(<0.005 \%)$ of negative business valuations at zero.

Private firms are not subject to the same disclosure laws as publicly traded companies, which makes it difficult to obtain detailed information on their ownership and performance. Equity stakes in these firms are also traded far less frequently than those in publicly listed companies, and when these transactions do take place, they are rarely a matter of public record. Consequently, the distribution of privately held business assets has remained one "the most important economic statistics for which there are no direct empirical data" (Anderson 2009). These same factors may also make it difficult for survey respondents to estimate the market value of their own businesses; accordingly, business valuations reported in the SCF may be subject to considerable error.

To address this possibility, we assess the robustness of our findings to two alternative approaches to measuring the value of privately held business assets. The first approach excludes 
farming and ranching businesses, as it is particularly difficult to separate personal from business assets in the agricultural sector. Results from an ancillary analysis using this alternative measure of non-farm business assets are presented in Part A of the Online Supplement. They are nearly identical to those reported in the main text.

The second approach augments our direct measure of business valuation (based on respondent estimates) with an indirect measure that imputes the value of privately held business assets by multiplying a household's annual business earnings by a cyclically adjusted price-toearnings $(\mathrm{P} / \mathrm{E})$ ratio for publicly traded firms. We deflate the $\mathrm{P} / \mathrm{E}$ ratio among public companies by $50 \%$ for sole proprietorships and by $10 \%$ for other private firms, following Anderson (2009), to account for the comparative difficulty of transferring equity in privately held firms. The strategy of using capitalized earnings to impute business valuations is also subject to considerable error. Reported earnings may conflate income from labor performed versus capital invested by the owner, especially among smaller, lower-value businesses. Annual business earnings are also highly volatile, and $\mathrm{P} / \mathrm{E}$ ratios for publicly traded companies offer only rough approximations for how private firms might be valued. To mitigate the overall degree of error, we averaged valuations reported directly by respondents with valuations imputed via capitalized earnings. Part B of the Online Supplement presents results from an ancillary analysis using this alternative measure, which are generally consistent with those reported in the main text.

Our explanatory variables of interest include education, firm age and scale, and access to business credit. The education level of the household head is coded as a binary variable indicating completion of a university degree. Firm age is measured with a series of binary variables indicating whether a household's business was started or acquired 0 to 9,10 to 24 , or more than 25 years ago. Firm scale is expressed as a series of binary variables measuring 
whether the household's business employs 0 to 9,10 to 99 , or more than 100 employees. For households that own multiple business, we record the age of the oldest firm and the size of the largest firm. We adopt relatively coarse measures of these variables to improve the precision with which we can estimate models for the conditional distribution of business assets. Analyses based on more fine-grained measures yield substantively similar results, although they are subject to greater sampling error.

Access to credit is expressed as a binary variable indicating whether a household is presently using a bank loan, mortgage, line of credit, or other consumer loan to finance or invest in a privately held business. Ideally, we would use information on total credit accessed from all sources by the respondent's business, but the SCF does not systematically collect this information. Instead, the survey asks (i) whether a household used particular kinds of consumer credit to fund or invest in a business, including mortgages and other consumer loans, and (ii) whether the household obtained a personally collateralized, cosigned, or guaranteed loan from a bank for their business. We use a positive response on either query as an indicator that an owner accessed credit for their business. This measure excludes respondents that obtained an unsecured or uncollateralized business loan; however, since the substantial majority of loans to private businesses are personally collateralized or guaranteed (Berger and Udall 1998; Steijvers et al. 2010), it still offers a reasonable proxy for overall access to business credit. Part $C$ of the Online Supplement reports results from an ancillary analysis that excludes the use of consumer credit for business purposes (with credit access measured exclusively via the use of bank loans), which are very similar to results reported in the main text. 


\subsection{Analyses}

Our analysis proceeds in three steps. First, we analyze overall changes in the distribution of privately held business assets, including trends in the proportion of the population who are business owners as well as the average value and variance of assets held by business owners. Second, we evaluate how changes in the distribution of privately held business assets are related to levels of education, access to credit, firm age, and firm scale. Third, we analyze the relationship between these changes and the concentration of privately held business assets at the population level.

To investigate trends in the distribution of privately held business assets, we estimate heteroscedastic hurdle models (Cragg 1971; Wooldridge 2010). This approach combines a selection model for whether or not an outcome of interest exceeds some boundary point, or "clears a hurdle," with models for the conditional mean and variance of the outcome given that it is above this lower bound. Hurdle models are ideal for the distribution of privately held business assets because it has a large mass point at zero, representing households that do not own businesses, together with a continuous distribution of positive asset valuations among private business owners.

The selection model in this analysis is for the probability that a household has a positively valued equity stake in a private business. This model can be formally expressed as:

$$
P\left(Y_{i t}>0\right)=\pi_{t}=\Phi(f(t ; \alpha))
$$

where $Y_{i t}$ denotes the total value of privately held business assets in which household $i$ has an ownership interest at time $t, \Phi(\cdot)$ denotes the standard normal cumulative distribution function, and $f(t ; \alpha)$ is a smooth function of time $t$ and a parameter vector $\alpha$. We consider two specifications for $f(t ; \alpha)$. The first is a simple linear specification, $f(t ; \alpha)=\alpha_{0}+$ 
$\alpha_{1}(t-1989)$, which allows for a crude directional assessment of overall trends. The second is a thin plate spline specification, which allows for more complex patterns of temporal change.

The selection model is then combined with models for the conditional mean and variance of assets among business owners. These models assume that the distribution of assets among business owners is log-normal, which we find to be a good approximation of the empirical distribution in the SCF. The log-normal distribution is a probability density model for variables that are right-skewed. If $Y_{i t}$ is log-normally distributed among private business owners, then $\log \left(Y_{i t}\right)$ is normally distributed in the same population. Its density is governed by two parameters, $\mu_{t}$ and $\sigma_{t}^{2}$, the mean and variance, respectively. Models for the conditional mean and variance of private business assets, given selection into ownership, can be formally expressed as:

$$
\begin{aligned}
& E\left(\log \left(Y_{i t}\right) \mid Y_{i t}>0\right)=\mu_{t}=g(t ; \beta) \\
& \operatorname{Var}\left(\log \left(Y_{i t}\right) \mid Y_{i t}>0\right)=\sigma_{t}^{2}=\exp (h(t ; \theta)) .
\end{aligned}
$$

In these models, $Y_{i t}$ is defined as previously, $\exp (\cdot)$ is the exponential function, $g(t ; \beta)$ is a smooth function of $t$ and the parameter vector $\beta$ that allows the mean to vary over time, and $h(t ; \theta)$ is another smooth function of $t$ and the parameter vector $\theta$ that allows the variance to change over time. As before, we consider both linear and thin plate spline specifications for these functions.

We estimate these models sequentially by the method of maximum likelihood (ML). That is, we first estimate Equation 1 by fitting a conventional probit model for whether or not a household owns an equity stake in a private business. Next, we estimate Equation 2 by fitting a conventional linear model for the natural log of asset values among private business owners. Finally, we estimate Equation 3 by fitting a gamma regression with a log link for the squared residuals obtained from Equation 2. When these models are specified using thin plate splines, 
ML estimates are obtained via penalized iteratively reweighted least squares, with a stringent penalty favoring smoother fits.

To investigate whether changes in the distribution of privately held business assets are related to our focal covariates, we stratify our models by these covariates and compare trends across subgroups. With education, for example, these models can be expressed as follows:

$$
\begin{aligned}
& P\left(Y_{i t}>0 \mid L_{i t}=l\right)=\pi_{l t}=\Phi(f(l, t ; \alpha)) \\
& E\left(\log \left(Y_{i t}\right) \mid Y_{i t}>0, L_{i t}=l\right)=\mu_{l t}=g(l, t ; \beta) \\
& \operatorname{Var}\left(\log \left(Y_{i t}\right) \mid Y_{i t}>0, L_{i t}=l\right)=\sigma_{l t}^{2}=\exp (h(l, t ; \theta)),
\end{aligned}
$$

where $L_{i t}$ denotes the highest level of education attained by the household head. Each model examines differences across levels of education by introducing a main effect for $L_{i t}$ together with two-way interactions between $L_{i t}$ and the terms capturing change over time. The same approach is used to model differences based on credit access, firm age, and firm scale. These variables, however, are defined only for private business owners, and thus they do not enter the selection model.

To evaluate the relationship between distributional shifts across levels of our focal covariates and trends in the concentration of privately held business assets, we analyze the top $1 \%$ share of these assets at the population level, which can be expressed in general terms as follows:

$$
S_{t}=\frac{\int_{0.99}^{1} F_{t}^{-1}(p) d p}{\int_{0}^{1} F_{t}^{-1}(p) d p},
$$

where $F_{t}^{-1}(\cdot)$ is the inverse of the cumulative distribution function for $Y_{i t}$. We focus on the top $1 \%$ share because it is an intuitive measure of concentration that is well-defined for non-negative distributions with support over zero. This measure tends to closely track other measures of 
concentration and satisfies, at least weakly, the main principles of inequality measurement (Leigh 2007; Jasso 2018).

We estimate the top $1 \%$ share of privately held business assets in two ways. First, we compute nonparametric estimates by taking the sum of all private business assets in the top sample percentile and dividing it by the total sum of business assets taken over the sample as a whole, separately for each wave. This estimate can be formally expressed as follows:

$$
S_{t}^{\mathrm{o}}=\left(\sum_{i} Y_{i t} \mathbf{1}_{\left[Y_{i t} \geq Q_{Y}(0.99)\right]}\right) /\left(\sum_{i} Y_{i t}\right),
$$

where $\mathbf{1}_{\left[Y_{i t} \geq Q_{Y}(0.99)\right]}$ is an indicator for whether $Y_{i t}$ exceeds the top sample percentile $Q_{Y}(0.99)$. Second, we compute parametric estimates based on our distribution model for privately held business assets. With this approach, we use estimates of the parameters $\left\{\pi_{t}, \mu_{t}, \sigma_{t}^{2}\right\}$ to simulate 10 million asset values at each time $t$. The simulated values are equal to $\tilde{Y}_{j t}=B_{j t} \exp \left(X_{j t}\right)$, for $j=1,2, \ldots, 10^{7}$, where $B_{j t} \sim \operatorname{Bernoulli}\left(\pi_{t}\right)$ and $X_{j t} \sim \operatorname{Normal}\left(\mu_{t}, \sigma_{t}^{2}\right){ }^{3}$ The sum of these values above the top percentile divided by the total sum over all simulated values, which can be expressed as

$$
S_{t}^{\mathrm{m}}=\left(\sum_{j} \tilde{Y}_{j t} \mathbf{1}_{\left[\tilde{Y}_{j t} \geq Q_{\widetilde{Y}}(0.99)\right]}\right) /\left(\sum_{j} \tilde{Y}_{j t}\right)
$$

provides a model-based estimate of the top $1 \%$ share.

The relationship of the covariates to changes in asset concentration is assessed by computing a set of counterfactual top $1 \%$ shares using model-based simulations similar to those outlined previously. This relationship is shaped by four underlying processes: (i) changes in the distribution of the covariates, (ii) changes in the likelihood of becoming a business owner across levels of the covariates, (iii) changes in mean asset values across levels of the covariates among business owners, and (iv) changes in the variance of asset values across levels of the covariates 
among business owners. We compute counterfactual estimates for the top $1 \%$ share that quantify the relationship between these changes and trends in the concentration of private business assets.

We first construct a counterfactual series that reflects how the top $1 \%$ share would have changed if, for example, the educational composition of the population had remained invariant since 1989, the baseline wave of the SCF. Specifically, we use estimates of the parameters $\left\{\pi_{l t}, \mu_{l t}, \sigma_{l t}^{2}\right\}$ at each level of education $l$ together with estimates of the educational composition of the population, $\tau_{t}$, to simulate 10 million asset values at each time $t$. The simulated values in this case are equal to $\breve{Y}_{j t}=\sum_{l} B_{j l t} \exp \left(X_{j l t}\right) \mathbf{1}_{\left[L_{j t}=l\right]}$ for $j=1,2, \ldots, 10^{7}$, where $L_{j t} \sim \operatorname{Bernoulli}\left(\tau_{1989}\right), B_{l j t} \sim \operatorname{Bernoulli}\left(\pi_{l t}\right)$ and $X_{l j t} \sim \operatorname{Normal}\left(\mu_{l t}, \sigma_{l t}^{2}\right)$. A model-based estimate of what the top $1 \%$ share would have been had the educational composition of the population remained the same since 1989 is then given by:

$$
S_{t}^{\mathrm{c}}=\left(\sum_{j} \breve{Y}_{j t} \mathbf{1}_{\left[\breve{Y}_{j t} \geq Q_{\breve{Y}}(0.99)\right]}\right) /\left(\sum_{j} \breve{Y}_{j t}\right) .
$$

We use similar procedures to examine the relationship between asset concentration and changes in the distribution of credit access, firm age, and firm scale.

We then construct a second counterfactual series that reflects how the top $1 \%$ share would have changed if differences across the covariates in the likelihood of becoming a business owner and/or in the average value of assets among business owners had remained invariant over time. A model-based estimate of this quantity can be expressed as:

$$
S_{t}^{\mathrm{c}+\mathrm{b}}=\left(\sum_{j} \ddot{Y}_{j t} \mathbf{1}_{\left[\ddot{Y}_{j t} \geq Q_{\ddot{Y}}(0.99)\right]}\right) /\left(\sum_{j} \ddot{Y}_{j t}\right),
$$

where $\ddot{Y}_{j t}=\sum_{l} B_{j l t} \exp \left(X_{j l t}\right) \mathbf{1}_{\left[L_{j t}=l\right]}$ for $j=1,2, \ldots, 10^{7}$ is simulated from $L_{j t} \sim \operatorname{Bernoulli}\left(\tau_{1989}\right), B_{l j t} \sim \operatorname{Bernoulli}\left(\pi_{l 1989}+\left(\pi_{t}-\pi_{1989}\right)\right)$ and $X_{l j t} \sim \operatorname{Normal}\left(\mu_{l 1989}+\right.$ $\left.\left(\mu_{t}-\mu_{1989}\right), \sigma_{l t}^{2}\right)$. In other words, $S_{t}^{\mathrm{c}+\mathrm{b}}$ is simulated from a model that constrains the population 
composition, as well as any differences in $\pi_{l t}$ and $\mu_{l t}$ across covariate levels $l$, to remain invariant from 1989 onward.

We evaluate $S_{t}^{\mathrm{m}}, S_{t}^{\mathrm{c}}$, and $S_{t}^{\mathrm{c}+\mathrm{b}}$ using ML estimates of their underlying model parameters from the thin plate spline specifications of Equations 1 to 3. We then plot differences between them over time and test the null hypothesis that they are equal to zero using bootstrap methods, which provides a concise summary of whether and how asset concentration at the population level is related to distributional changes involving the covariates of interest.

All analyses are weighted to adjust for the SCF sample design, and inferences target the full population of American households. Standard errors are computed using bootstrap replicate weights. The public files supplied by the SCF fill in missing values using multiple imputation with 5 replications. All point estimates and bootstrap standard errors in this analysis are combined across imputations following Rubin (1987). Analyses evaluating the relative fit of different models are performed on a single set of imputations and implemented using the weighted pseudo-likelihood (Lumley and Scott 2015; Wood et al. 2016).

\section{RESULTS}

\subsection{The Statics of Privately Held Business Assets}

Figure 1 summarizes the overall distribution of privately held business assets across U.S. households. The first panel contains a histogram of the following quantity:

$$
Z_{i t}=\left\{\begin{array}{cc}
0 & \text { if } Y_{i t}=0 \\
\log \left(Y_{i t}\right) & \text { if } Y_{i t}>0
\end{array}\right.
$$

where $Y_{i t}$ denotes the value of a household's business assets in real dollars. This panel indicates that around $90 \%$ of the population does not own any equity in a privately held business and that the household distribution of business assets is extremely right skewed. The $95^{\text {th }}$ and $99^{\text {th }}$ 
percentiles of this distribution are about $\$ 160 \mathrm{~K}$ and $\$ 2.1 \mathrm{M}$, respectively, whereas the $90^{\text {th }}$ percentile is nearly $\$ 0$.

\section{[INSERT FIGURE 1 HERE]}

The second panel of Figure 1 presents a histogram for log assets among the subpopulation of business owners and overlays a normal density curve for reference, which indicates that our assumed distribution model provides a reasonable fit to the observed data. Even among business-owning households, the distribution of business assets remains highly right skewed. The $10^{\text {th }}$ percentile of this distribution equates to an asset valuation of about $\$ 7 \mathrm{~K}$, while the median asset valuation stands at $\$ 118 \mathrm{~K}$. Valuations at the $90^{\text {th }}, 95^{\text {th }}$, and $99^{\text {th }}$ percentiles are about $\$ 1.7 \mathrm{M}, \$ 4.0 \mathrm{M}$, and $\$ 14.7 \mathrm{M}$, respectively. In other words, top business-owning households control equity positions that are orders of magnitude more valuable than the equity controlled by the "typical" business-owning household.

\subsection{The Dynamics of Privately Held Business Assets}

Table 1 presents a set of hurdle models for trends in the distribution of privately held business assets over time. The first column presents selection models for the probability that a household owns a private business, while the second and third columns contain models for the conditional mean and variance of $\log$ assets among the subpopulation of business owners. The upper panel presents parameter estimates from a set of linear specifications for these models. The lower panel presents Akaike Information Criteria (AIC; Wood et al. 2016) for evaluating the relative performance of the linear versus spline specifications. Lower AIC values indicate a superior balance between goodness of fit and model parsimony. The selection models presented in Table 1 provide little evidence of change over time in the relative number of households that own 
businesses; the conditional mean models indicate that business asset valuations generally increased between 1989 and 2019; and the conditional variance models indicate that the distribution of assets among private business owners has grown significantly more dispersed, or unequal, since the late 1980 s.

\section{[INSERT TABLE 1 HERE]}

In Part D of the Online Supplement, we present separate estimates for these models by industry and occupation of the household head. We find trends similar to those outlined above in both the goods-producing and service sectors and among professionals and other occupations, although there is some evidence that those in goods-producing industries and professional occupations have become increasingly likely to select into business ownership over time. In the same section, we also present estimates for the subset of privately held firms that fall into the category of "small and medium-sized enterprises" (i.e., private firms with fewer than 500 employees) and for businesses that are "actively managed" by the household. Trends based on each subset of firms are also very similar to those outlined previously.

Figure 2 graphically represents the spline models of trends in the distribution of privately held business assets. The upper left panel presents estimates for the proportion of households with any ownership stake in a private business between 1989 and 2019, indicating that the relative number of business owners remained flat over time at just above $10 \%$. The upper right panel displays trends in the estimated mean of log assets among business-owning households, which demonstrates that average business valuations have increased over the same period. The lower left panel displays the estimated conditional variance, showing that asset dispersion among business owners grew substantially, especially during the 2000s.

[INSERT FIGURE 2 HERE] 
The lower right panel of Figure 2 summarizes trends in the concentration of business assets among the total population of households as measured by the top $1 \%$ share. The solid line represents our nonparametric estimates of the top $1 \%$ share, $S_{t}^{o}$, while the dashed line represents our parametric estimates, $S_{t}^{\mathrm{m}}$, simulated from the hurdle model with a spline function in time. Both sets of estimates indicate that privately held business assets are extremely concentrated among top business owners and that this distribution became even more unequal over the past several decades. In the late 1980 s and early 1990 s, the top $1 \%$ of households owned about $70 \%$ of all equity in the privately held business sector. Over the next three decades, the share of business assets owned by the top $1 \%$ of households increased to nearly $80 \%$. In comparison, the top $1 \%$ share computed over the distribution of financial assets was just under $40 \%$ at the 2019 wave of the SCF. ${ }^{4}$ The same quantity computed over the distribution of real estate assets registers at about $30 \%$. This pattern indicates that privately held business assets are among the most concentrated forms of capital in the U.S. economy and are becoming even more concentrated over time. In the following sections, we consider the evidence for several potential explanations of this trend.

\subsection{The Role of Education}

Table 2 presents a set of hurdle models that evaluate the relationship between household head education, our proxy for non-routine skills, and trends in the distribution of privately held business assets. These results suggest that education is closely related to the asset distribution and that this relationship has changed over time in complex ways. Results from the selection model indicate that while college graduates are much more likely to own a private business than individuals with less education, the size of this ownership gap has not changed over time. Results 
from the conditional mean model indicate that business owners with a college degree control substantially more equity in the private business sector than those with less education and that these differences have widened substantially. In 1989, private business owners who graduated from college held assets worth $41.7 \%$ more than those held by owners with less education, and this gap increased by an estimated $1.3 \%$ per year from then on. Results from the conditional variance models suggest that trends in asset dispersion also differ across levels of owner education.

\section{[INSERT TABLE 2 HERE]}

Figure 3 graphically summarizes the relationship between education and the distribution of privately held business assets. The upper left panel displays a smoothed trend in the proportion of college graduates in the overall population, while the upper right panel displays point estimates from the spline model for selection into business ownership. These two panels show that even as the relative number of college graduates steadily increased within the total population, educational differences in the probability of owning a private business remained unchanged. The lower left panel displays results from the conditional mean model for log assets among business-owning households, which demonstrate that the business assets owned by college graduates steadily increased in value while those owned by household heads with less education stagnated. The lower right panel presents trends in the conditional variance of log assets, indicating that asset dispersion among business owners with a college degree also increased at a steady rate over time, while asset dispersion among owners with less education appears more cyclical, rising or falling in line with broader economic cycles.

[INSERT FIGURE 3 HERE] 
Figure 4 summarizes the link between these dynamics and the concentration of privately held business assets at the top of the distribution. The dot-dashed line in this figure displays the difference between model-based estimates of the top $1 \%$ share, $S_{t}^{\mathrm{m}}$, and a set of counterfactual estimates, $S_{t}^{c}$, that capture what the top $1 \%$ share would have been if the educational composition of the population had remained invariant since 1989. The dashed line displays the difference between model-based estimates of the top 1\% share and a second set of counterfactual estimates, $S_{t}^{\mathrm{c}+\mathrm{b}}$, that capture how this quantity would have changed if educational differences in both the likelihood of becoming a business owner and the average value of log assets among business owners had also remained invariant from 1989 onward. The asterisks in this figure denote that $p<0.05$ from a bootstrap z-test of the null hypothesis that the counterfactual difference is equal to zero.

\section{[INSERT FIGURE 4 HERE]}

The dot-dashed line in Figure 4 is generally flat and never deviates significantly from zero, implying that the increase in the proportion of college graduates had little influence by itself on the concentration of business assets among the top 1\%. The dashed line suggests that growing differences in asset valuations between more and less educated business owners inflated asset concentration at the population level. Growth in the top $1 \%$ share of privately held business assets would have been about 2 percentage points lower had the educational composition of the population, educational differences in selection into business ownership, and educational differences in mean asset valuations among business owners remained invariant since 1989. Given that educational differences in selection into business ownership changed very little over time, this effect can be attributed to growing polarization in asset valuations across business owners with versus without a college degree. 
In summary, the relationship between education and selection into business ownership has remained remarkably stable over the past three decades. Among business owners, asset growth was steady for those with a college degree but stagnated for those with less education, contributing to rising asset concentration at the population level. These trends align with arguments that link skill-biased technological change to rising asset concentration in the privately held business sector.

\subsection{The Role of Credit Access}

Table 3 presents models that evaluate the relationship between access to credit and the distribution of privately held business assets. Because the SCF is cross-sectional and only collects information about business financing from business owners, we cannot model selection into business ownership based on the relative difficulty of accessing credit among the total population of households. Instead, we model how access to business credit is related to the conditional mean and variance of the asset distribution among the subpopulation of business owners.

\section{[INSERT TABLE 3 HERE]}

The upper panel of Table 3 presents results from models with linear trends that differ depending on whether a household accessed credit to finance their business, while the lower panel presents AIC statistics for comparing these models against spline specifications that allow more complex nonlinear trends. Results from the conditional mean model indicate that business owners who accessed credit controlled assets that were much more valuable, on average, than those who did not access credit. They also indicate that these differences widened substantially over time. In 1989, business owners who accessed credit owned about double the assets of 
owners who did not; thereafter, this gap increased by about $1.9 \%$ per year. Results from the conditional variance models show that the asset distribution is also considerably less variable among business owners who accessed credit compared with owners who did not.

Figure 5 summarizes these relationships graphically. The upper left panel presents a smoothed trend in the proportion of private business owners who accessed credit to finance their firms. In line with our predictions, this trend suggests that the relative number of business owners who accessed credit has declined substantially over time-from $30 \%$ of business owners in 1989 to less than $20 \%$ in 2019 . The upper right and lower left panels display point estimates from spline models for the conditional mean and variance of log assets, respectively. As credit access among business owners declined overall, these estimates indicate that asset valuations among those who did access credit increased at a faster rate than asset valuations among owners who did not, while asset dispersion within both groups grew modestly.

\section{[INSERT FIGURE 5 HERE]}

The lower right panel summarizes the relationship between these distributional changes and the concentration of business assets among the top $1 \%$ of households. The dot-dashed line displays the difference between model-based estimates of the top $1 \%$ share and a set of counterfactual estimates that capture what this share would have been had the proportion of business owners with access to credit remained stable at its 1989 level. The dashed line displays the difference between model-based estimates and a second set of counterfactual estimates that additionally capture how the top $1 \%$ share would have changed if differences in the average value of $\log$ assets between owners with and without access to credit had remained invariant from 1989 onward. The dot-dashed line declines over time and begins to deviate significantly from zero after the early 2000 s, indicating that the steady reduction in the proportion of business 
owners with credit access contributed to rising asset concentration at the population level. The dashed line follows a similar pattern. It suggests that growth in the top $1 \%$ share of privately held business assets would have been about 2 percentage points lower if the proportion of business owners accessing credit and the mean difference in log assets between owners with versus without access to credit had both remained stable since 1989.

To summarize, credit access among private business owners declined since the late 1980s and became a stronger predictor of asset valuations over the same period. These patterns signal the emergence of an increasingly wealthy subset of business owners at the top of the asset distribution, whose defining features appear to include access to credit for their firms. They are also consistent with an account that links changes in banking strategy and structure in the modern financialized era to rising asset concentration in the privately held business sector.

\subsection{The Role of Firm Age and Scale}

Figure 6 describes the link between firm age and the distribution of private business assets. The upper left panel shows smoothed trends in the proportion of business owners whose firm is between 0-9 years, 10-24 years, or 25+ years old. The age distribution of businesses shifted considerably from 1989 to 2016 . The proportion of owners with firms between 0-9 years old declined from about $40 \%$ to $30 \%$; the proportion with firms $25+$ years old increased from about $20 \%$ to $30 \%$; and the proportion with firms between 10-24 years old remained stable at about $40 \%$.

\section{[INSERT FIGURE 6 HERE]}

Although private businesses aged substantially over this period, data from the SCF indicate that the relationship between firm age and asset valuations has not changed appreciably 
over time. The upper right and lower left panels of Figure 6 display point estimates from spline models for the conditional mean and variance of log assets among households that own firms of different ages. Firm age is a strong predictor of asset valuations in general—older firms are, on average, substantially more valuable than younger firms, as expected. This relationship, however, has remained stable over time. The lower right panel of Figure 6 summarizes the link between firm age and the concentration of business assets within the top $1 \%$ of households. The counterfactual comparisons presented here provide no indication that changes in the age distribution of firms or in mean valuations are linked to rising asset concentration. Instead, they suggest that growth in asset concentration was driven by increasing dispersion in the value of business assets within age categories.

\section{[INSERT TABLE 4 HERE]}

These findings are confirmed in the upper panel of Table 4, which presents results from linear models evaluating the relationship of firm age to asset valuations. As in Figure 6, these results provide little evidence that the link between firm age and the distribution of business assets changed over time. The only appreciable change indicated by the results in Table 4 is a steady increase in the variance of log assets, which occurred at roughly the same rate across all business-owning households regardless of their firm's age.

The lower panel of Table 4 presents estimates from models evaluating the relationship between the scale and valuation of an owner's business. Estimates for models of the conditional mean indicate that larger firms are, as expected, much more valuable than smaller firms. Moreover, these estimates also indicate that returns to scale increased over time, as asset valuations for larger firms grew steadily while those for smaller firms stagnated. Estimates for models of the conditional variance indicate that trends in the dispersion of asset valuations also 
differ by firm scale. The asset distribution among households that own a medium-sized business grew less dispersed over time, while the distribution among households that own either large or small firms became more variable.

\section{[INSERT FIGURE 7 HERE]}

Figure 7 graphically summarizes the link between firm scale and the distribution of private business assets. The upper left panel shows smoothed trends in the proportion of private business owners whose firm has between 0-9, 10-99, or 100+ employees. The upper right and lower left panels display point estimates from spline models for the conditional mean and variance of log assets among households that own firms of different sizes. The lower right panel summarizes the link between firm scale and the concentration of privately held business assets among top owners. Taken together, these results indicate that the size distribution of firms remained stable over time, while the relative difference in valuations for larger versus smaller firms widened substantially. Had returns to firm scale remained invariant since 1989, growth in the top $1 \%$ share of private business assets would have been about 4 percentage points lower. However, we note that these estimates are subject to considerable sampling error and, in many cases, only reach marginal thresholds for statistical significance.

To summarize, returns to firm scale increased over time and likely had an inflationary influence on asset concentration at the population level. Although the age distribution of private firms also grew significantly older, age-based differences in the valuation of firms remained stable, and the shifting age distribution was not itself linked with trends in asset concentration. These results are partly consistent with an account that connects growth in the concentration of private business assets with rising market power. 


\section{DISCUSSION}

Privately held businesses were central to the analyses of classical sociologists attempting to understand the dynamics of early capitalist societies (Marx 1993 [1894]; Weber 2003 [1889]), and they continue to play a vital role in the U.S. economy today. Yet the private business sector has received surprisingly little attention in contemporary sociological research. Within economic sociology, business organizations and the economic and social transformations that reshape them remain important objects of inquiry, but interest in privately held firms pales in comparison to interest in their publicly traded counterparts (e.g., Davis 2009; Fligstein 1990; Roy 1997; see Ruef and Lounsbury 2007 and Thornton et al. 2011 for noteworthy exceptions). And while scholarship on social stratification examines the distribution of many different types of resources (e.g., Killewald et al. 2017; Lin 1999; Morris and Western 1999), the distribution of privately held business assets has attracted relatively little interest.

We extend these scholarly traditions by investigating how privately held business assets are distributed among U.S. households and by examining how recent economic transformations potentially contributed to these dynamics over time. Our first contribution is to offer a benchmark description of the distribution of private business assets in the United States. Using data from the SCF, we show that this distribution is extremely concentrated at the top and has only grown more concentrated in recent decades. The proximate causes of this trend include stagnation in the relative number of households that own equity in private businesses, steady growth in the valuations of businesses controlled by top owners, and inert valuations in the lower segments of the asset distribution. Our second contribution is to establish some of the broad social processes that may have shaped the historical evolution of this distribution. Although available data are too crude to conclusively evaluate the distal causes of this trend, our findings 
suggest that the uneven impact of technological change, the financialization of banking, and rising market power may have contributed to growth in private business asset concentration since the late 1980s. Rising returns to highly educated business owners at a time of technological change, evolving patterns of business credit allocation in the modern financialized era, and increasing returns to firm scale in a period of expanding market power all appear to have played a role. Below, we discuss the implications of these findings for theory, research, and policy.

\subsection{The Privately Held Business Sector: Democratizing or Disequalizing?}

Data from the SCF indicate that privately held business assets may be the most unequally distributed form of capital in the modern U.S. economy. This finding complicates conventional narratives about privately held businesses in American society, which often present these firms as powerful counterweights to inequality, widely accessible vehicle for building wealth, or important stepping stones to economic mobility, especially for marginalized groups (e.g., Means 2016; Shane 2013; Yellen 2014). If a vibrant and accessible private business sector helps to secure widespread prosperity and disperse economic power, as actors across the political spectrum have contended (e.g., Mitchell and Holmberg 2020; Reagan 1983), our results present cause for concern. In contrast to a vision of the privately held business sector as "democratizing" and relatively diffuse, our findings suggest that small group of elite business owners currently control the vast majority of assets within it.

\subsection{Implications for Stratification Research and Economic Sociology}

Our findings also hold implications for the rapidly expanding literature on wealth inequality and for research in economic sociology. Because wealth inequality affects multiple domains of social 
life, from the functioning of democratic institutions (Gilens 2014) to prospects for social mobility (Braga et al. 2017) to population health (Nowatzki 2012), it is especially important to develop a comprehensive understanding of its causes. In the most recent review of research on wealth inequality, "businesses" are mentioned only a handful of times in passing (Killewald et al. 2017). Yet the findings of our study raise the possibility that concentration in the privately held business sector could be a powerful contributor to this trend. Our results suggest that if privately held business assets were distributed equally among U.S. households, the top $1 \%$ share of total wealth would shrink by more than two-thirds, from $37 \%$ to $10 \%$, at the most recent wave of data collection. Although a more systematic investigation of the relationship between the distribution of private business assets and wealth inequality remains a task for future research, this pattern implies that scholarship in stratification might benefit from deeper engagement with this vehicle for capital accumulation.

Scholarship in economic sociology might also benefit from closer attention to the privately held business sector. With the exception of the entrepreneurship literature (Ruef and Lounsbury 2007; Thornton et al. 2011), research in economic sociology only rarely examines privately held firms. Although this may be partially due to data limitations, since reliable information on the structures, operations, and activities of private firms is notoriously hard to find (Anderson 2009), a heavy focus on the rise and evolution of the publicly traded corporation has also likely played a role (e.g. Berle and Means 1932; Fligstein 1990; Roy 1997; Davis 2009). Implicitly or explicitly, economic sociologists tend to conceptualize privately held firms as vestiges of a bygone economic era, or at the very least, as less socially, politically, and economically relevant than their publicly traded counterparts (e.g. Perrow 2000; Berle and Means 1932; Roy 1997). Yet our findings suggest that the gulf between distributional dynamics 
on Wall Street and Main Street is not nearly as wide as the conventional wisdom implies. Trends like these highlight the need for scholars of economic inequality to devote closer attention to this comparatively overlooked sector of the economy.

Other recent developments in the U.S. economy also indicate that the predominant focus on publicly traded companies may be due for a reconsideration. For example, the number of listed companies has steadily declined since the early 2000s (Doidge, Karolyi, and Stulz 2015; Kahle and Stulz 2017), a trend that is only likely to enhance the relative salience of privately held firms. Similarly, the recent explosive rise of private equity has underscored the central economic importance of non-public capital markets and the actors that inhabit them (Appelbaum and Batt 2014).

Our findings also indicate that the impact of recent economic transformations, including technological changes that reward non-routine skills and the financialization of banking, may be even broader than previously recognized. Research on skill-biased technological change has focused primarily on consequences for labor markets and wages (Autor et al. 2006; Bound and Johnson 1992; Hout 2012), while research on the financialization of banking has centered on consequences for financial markets and their stability (Carruthers 2020; Krippner 2011; Pernell 2020). Yet these effects may stretch well beyond labor and financial markets. Our results imply that they have influenced distributional dynamics in the privately held business sector as well.

\subsection{Implications for Policy}

Our findings also help to shed new light on recent policy outcomes. Several forms of government support to "small businesses," including the recent Paycheck Protection Program (PPP) introduced to mitigate the economic fallout of the COVID-19 pandemic, have attracted 
controversy because they distribute a sizeable proportion of funds to businesses the public does not think of as small (Kurtzleben 2020; Popken and Lehren 2020). Our results suggest that these controversies may reflect deeper structural issues that have afflicted the privately held business sector for some time. Given the extreme concentration of capital we identify in this sector, any aid distributed proportional to firm size, even among so-called "small and medium-sized enterprises," can be expected to mainly accrue to a small number of high-value firms and their wealthy owners. Methods of policy administration that entrust the distribution of government support to commercial banks, as the PPP and many other programs do, can also be expected to buttress the inequalities uncovered in this study. Commercial banks already have their own reasons for diverting credit towards larger and higher-value businesses; allowing their perceptions of creditworthiness to guide the distribution of government aid is likely to reproduce similar allocative patterns here. We think current forms of government support to the private business sector may be at risk of reinforcing asset concentration, and wealth inequality by extension, unless they are specifically designed to avoid this outcome.

\subsection{Limitations and Directions for Future Research}

The results of our analysis must be interpreted cautiously owing to several limitations. First, our measure of business equity may be subject to considerable error, given the difficulty of attaching accurate valuations to privately held firms. The SCF attempts to mitigate the degree of error by interviewing the most financially knowledgeable member of the household and timing the survey to coincide with tax filing deadlines. We also attempt to assess the robustness of our key findings by replicating them using several different approaches to measurement. Yet the possibility 
remains that our inferences may be distorted by systemic, unforeseen errors in the valuation of a household's private business assets.

Second, our analysis is limited because the SCF provides only crude measures for evaluating potential drivers of asset concentration. For example, we lack detailed information on industry and occupation, business financing, and non-routine skills. We also lack a defensible identification strategy that might justify causal inferences about the association of firm and owner characteristics with business valuations. In Part E of the Online Supplement, we show that the relationships between our focal covariates and the distribution of private business assets hold regardless of whether they are evaluated separately or jointly using a single model. Nevertheless, without more detailed measures, data on a range of likely confounders, or a compelling method for untangling reciprocal causal relationships (e.g., between credit access and asset valuation), these results must be interpreted as merely suggestive.

Our findings also point toward new directions for future research. Future research might examine how the trends uncovered in this study differ by race and gender. Prior research documents stark disparities in outcomes across businesses owned by members of different demographic groups (e.g. Fairlie and Robb 2007; Thebaud and Sharkey 2016), but the majority of this literature analyzes disparities at a single point in time, does not consider differences in business valuations, and has not linked these differences to wealth inequalities across groups. One particularly promising line of inquiry might be to examine how sociodemographic differences in the ownership of business assets have evolved in recent decades and to evaluate their contribution to stubbornly persistent wealth gaps.

Future research might also examine yet another channel through which privately held businesses could contribute to growing wealth inequality: shielding owners from taxation and 
regulation. Several recent studies show how elaborate networks of privately held firms allow wealthy investors to shelter their assets and income in ways that regularly skirt with illegality (Hoang forthcoming; Zucman 2015), raising important questions about the role of this organizational form in concealing "the hidden wealth of nations."

Finally, future research might undertake a more systematic evaluation of how the growing influence of private equity has contributed to distributional dynamics in the privately held business sector. Typically organized as a limited partnership of institutional investors (e.g., pension funds or insurance companies) and/or qualified clients (e.g., high net worth households), a private equity fund is a type of pooled investment vehicle that strategically purchases controlling positions in a portfolio of privately held companies. The rapid expansion of private equity funds may have contributed to rising asset concentration, particularly at the upper extremes of the distribution, by taking large public firms private or by increasing the ease with which high net worth households could invest passively and diversely in the private business sector. While the limitations of the SCF preclude a direct evaluation of this particular mechanism, future research might draw from other data sources to examine its influence more rigorously.

Although the expansion of private equity was likely influential for the processes considered here, results from additional analyses suggest that our key findings are not entirely reducible to its effects. Even after limiting our focus to small- and medium-sized businesses, which are much less likely to be targets of private equity funds, we find very similar results (see Table D.3). We also find similar results after limiting our focus to actively managed privately businesses, a strategy that explicitly excludes passive investments made by limited partners in a private equity fund (see Table D.4). 


\section{CONCLUSION}

Although our analysis suffers from nontrivial limitations, it also represents a necessary and important first step towards cultivating a more vibrant sociological scholarship on privately held businesses. Data limitations and conceptual problems alike have hindered the development of research in this area. The popular characterization of the privately held business sector as a relatively democratic or elite-disrupting domain of the economy, for example, has likely discouraged sociologists interested in rising inequality from looking this way for answers. With several key distributional patterns now established, we hope that our study sparks renewed interest in privately held businesses, their owners, and their influence in American economy and society. 


\section{ENDNOTES}

1. The use of standardized lending criteria makes it easier for banks to evaluate borrowers outside of their local communities. As Oppenheim (1997a: 1) explains, the transactional lending model " $\mathrm{t}[\mathrm{ook}]$ away the relationship and the geographic constraints and ma[de private business lending] more of a commodity business."

2. About $80 \%$ of business-owning households report being engaged in active management.

3. Although the log-normal distribution generally provides a good fit to data, it moderately overstates the level of inequality in the upper fractiles of the asset distribution. To adjust for this, we deflate the conditional variance in all simulations by $10 \%$.

4. Financial assets include all transaction accounts, certificates of deposit, bonds, stocks, pooled investment funds, retirement accounts, life insurance, and other managed assets. 


\section{REFERENCES}

Acemoglu, Daron and Pascual Restrepo. 2017. "Robots and Jobs: Evidence from U.S. Labor Markets.” NBER Working Paper 23285.

Aldrich, Howard E. 2007. Organizations and Environments. Stanford, CA: Stanford University Press.

Anderson, Patrick L. 2009. "The Value of Private Businesses in the United States.” Business Economics 44:87-108.

Appelbaum, Eileen and Rosemary Batt. 2014. Private Equity at Work: When Wall Street Manages Main Street. New York: Russell Sage Foundation

Asker, John, Joan Farre-Mensa, and Alexander Ljungqvist. 2011. “Comparing the Investment Behavior of Public and Private Firms." NBER Working Paper 17394.

Autor, David, David Dorn, Lawrence F. Katz, Christina Patterson, and John Van Reenen. 2017. “Concentrating on the Fall of the Labor Share." American Economic Review 107:180185.

Autor, David, Frank Levy, and Richard J. Murnane. 2003. “The Skill Content of Recent Technological Change: An Empirical Exploration." Quarterly Journal of Economics 118:1279-1333.

Autor, David, Lawrence F. Katz, and Melissa S. Kearney. 2006. "The Polarization of the U.S. Labor Market." American Economic Review 96:189-194.

Azar, Jose, Ioana Marinescu, and Marshall Steinbaum. 2020. "Labor Market Concentration.” Journal of Human Resources (online prepublication).

Baker, Jonathan B. and Steven C. Salop. 2015. "Antitrust, Competition Policy, and Inequality." The Georgetown Law Journal 104:1-28. 
Barkai, Simcha. 2020. "Declining Labor and Capital Shares." The Journal of Finance 75:24212463.

Berger, Allen N., and Gregory F. Udell. 1998. "The Economics of Small Business Finance: The Roles of Private Equity and Debt Markets in the Financial Growth Cycle." Journal of Banking and Finance. 22(6): 613-673.

Berger, Allen N. and Gregory F. Udell. 2002. "Small Business Credit Availability and Relationship Lending: The Importance of Bank Organisational Structure" The Economic Journal 112(447): 32-53.

Berger, Allen, Anil Kashyap, and Joseph M. Scalise. 1995. 'The Transformation of the U.S. Banking Industry: What a Long, Strange Trip It's Been" Brookings Papers on Economic Activity (2): 155-218.

Berle, Adolf A. and Gardiner C. Means. 1932. The Modern Corporation and Private Property. New York: Commerce Clearing House.

Bitler, Marianne P., Alicia M. Robb, and John D. Wolken. 2001. "Financial Services Used by Small Businesses: Evidence from the 1998 Survey of Small Business Finances." Federal Reserve Bulletin 87:183-205.

Board of Governors of the Federal Reserve System. 2019. "Survey of Consumer Finances." https://www.federalreserve.gov/econres/scfindex.htm.

Bound, John and George E. Johnson. 1992. "Changes in the Structure of Wages in the 1980s: An Evaluation of Alternative Explanations.” American Economic Review 82:371-392.

Braga, Breno, Signe-Mary McKernan, Caroline Ratcliffe, and Sandy Baum. 2017. Wealth Inequality is a Barrier to Education and Social Mobility. Washington, DC: The Urban 
Institute. https://www.urban.org/research/publication/wealth-inequality-barriereducation-and-social-mobility.

Brynjolfsson, Erik and Andrew McAfee. 2011. Race Against the Machine. Digital Frontier Press. Carruthers, Bruce G. 2020. "Law, Governance, and Finance: Introduction to the Theory and Society Special Issue.” Theory and Society 49:151-164.

Cragg, John G. 1971. "Some Statistical Models for Limited Dependent Variables with Application to the Demand for Durable Goods." Econometrica 39:829-844.

Cooper, Arnold C., F. Javier Gimeno-Gascon, and Carolyn Woo. 1994. "Initial Human and Financial Capital as Predictors of New Venture Performance.” Journal of Business Venturing 9:371-395.

Curran, James and Roger Burrows. 1986. "The Sociology of Petit Capitalism: A Trend Report." Sociology 20:265-279.

Davis, Gerald R. 2009. Managed by the Markets: How Finance Re-Shaped America. New York: Oxford University Press.

Davis, S. J., J. Haltiwanger, R. Jarmin, and J. Miranda. 2007. "Volatility and Dispersion in Business Growth Rates: Publicly Traded versus Privately Held Firms." Pg. 107-180 in NBER Macroeconomics. Cambridge, MA: MIT Press.

De Loecker, Jan, Jan Eeckhout, and Gabriel Unger. 2020. "The Rise of Market Power and the Macroeconomic Implications.” The Quarterly Journal of Economics 135:561-644.

Dobbin, Frank and Dirk Zorn. 2005. "Corporate Malfeasance and the Myth of Shareholder Value." Pp. 179-198 in Political Power and Social Theory, Vol 17. Emerald Group Publishing Limited. 
Dymski, Gary. 1999. The Bank Merger Wave: The Economic Causes and Social Consequences of Financial Consolidation. Armonk, NY: M.E. Sharpe Inc.

Fairlie, Robert W. and Alicia Robb. 2007. "Why Are Black-Owned Businesses Less Successful Than White-Owned Businesses? The Role of Families, Inheritances, and Business Human Capital.” Journal of Labor Economics 25:289-323.

Fishman, Charles. 2007. The Wal-Mart Effect. London: Penguin.

Fligstein, Neil. 1990. The Transformation of Corporate Control. Cambridge, MA: Harvard University Press.

Fligstein, Neil and Adam Goldstein. 2015. "The Emergence of a Finance Culture in American Households, 1989-2007." Socio-Economic Review 13(3): 575-601.

Gilens, Martin. 2014. Affluence and Influence: Economic Inequality and Political Power in America. Princeton, NJ: Princeton University Press.

Graetz, Georg and Guy Michaels. 2018. "Robots at Work." Review of Economics and Statistics 100:753-768.

Greve, Arent and Janet W. Salaff. 2003. "Social Networks and Entrepreneurship.” Entrepreneurship: Theory and Practice 28:1-22.

Griliches, Zvi. 1969. “Capital-Skill Complementarity.” Review of Economics and Statistics $51: 465-468$.

Grullon, Gustavo, Yelena Larkin, and Roni Michaely. 2019. “Are US Industries Becoming More Concentrated?" Review of Finance 23:697-743.

Haltiwanger, John, Ron Jarmin, and Javier Miranda. 2012. "Where Have All the Young Firms Gone?” Business Dynamics Statistics. U.S. Census Bureau. 
Hathaway, Ian and Robert Litan. 2014. "The Other Aging of America: The Increasing Dominance of Older Firms.” Economic Studies at Brookings. The Brookings Institute. Haynes, George W., Charles Ou, and Robert Berney. 1999. "Small Business Borrowing from Large and Small Banks" Pp. 287-327 in Business Access to Capital and Credit, ed. Jackson Blanton, Alicia Williams, and Sherri Rhine.

Hoang, Kimberly Kay. Forthcoming. Playing in the Gray: Offshoring and Foreign Investments in Frontier Markets. Princeton, NJ: Princeton University Press.

Hout, Michael. 2012. "Social and Economic Returns to College Education in the United States." Annual Review of Sociology 38:379-400.

Jasso, Guillermina. 2018. “Anything Lorenz Curves Can Do, Top Shares Can Do: Assessing the TopBot Family of Inequality Measures." Sociological Methods and Research (online prepublication).

Kaldor, Nicholas. 1934. "The Equilibrium of the Firm.” Economic Journal 44:60-76.

Karahan, Faith, Benjamin Pugsley, and Aysegul Sahin. 2019. "Demographic Origins of the Startup Deficit.” NBER Working Paper 25874.

Khan, Lina and Sandeep Vaheesan. 2017. "Market Power and Inequality: The Antitrust Counterrevolution and its Discontents." Harvard Law \& Policy Review 11:235-294.

Killewald, Alexandra, Fabian T. Pfeffer, and Jared N. Schachner. 2017. "Wealth Inequality and Accumulation.” Annual Review of Sociology 43:379-404.

Kihlstrom, Richard E. and Jean-Jacques Laffont. 1979. “A General Equilibrium Entrepreneurial Theory of Firm Formation based on Risk Aversion.” Journal of Political Economy 87:719-748. 
Krippner, Greta R. 2011. Capitalizing on Crisis: The Political Origins of the Rise of Finance. Cambridge, MA: Harvard University Press.

Kurtzleben, Danielle. 2020. "Not-so-small Business Continue to Benefit from PPP Loans." https://www.npr.org/2020/05/04/850177240/not-so-small-businesses-continue-to-benefitfrom-ppp-loans

Lareau, Annette. 2015. "Cultural Knowledge and Social Inequality.” American Sociological Review 80:1-27.

Lazear, Edward P. 2005. “Entrepreneurship.” Journal of Labor Economics 23:649-680.

Lee, Jesse. 2010. "Small Businesses: The Backbone of America's Economy.” The White House Archives. https://obamawhitehouse.archives.gov/blog/2010/05/13/small-businessesbackbone-americas-economy.

Leigh, Andrew. 2007. "How Closely Do Top Income Shares Track Other Measures of Inequality?” Economic Journal 117:F619-F633.

Levine, Ross and Yona Rubinstein. 2017. "Smart and Illicit: Who Becomes an Entrepreneur and Do They Earn More?" The Quarterly Journal of Economics 132:963-1018.

Lin, Ken-Hou and Megan Tobias Neely. 2020. Divested: Inequality in the Age of Finance. New York: Oxford University Press.

Lin, Nan. 1999. "Social Networks and Status Attainment." Annual Review of Sociology 25: 46787.

Lumley, Thomas and Alastair Scott. 2015. "AIC and BIC for Modeling with Complex Survey Data." Journal of Survey Statistics and Methodology 3:1-18.

Marx, Karl. 1993 [1894]. Capital: Volume III. London: Penguin Classics. 
Means, Benjamin. 2016. "Wealth Inequality and Family Businesses.” Emory Law Journal 65: 937-986.

Mills, Karen G. 2019. Fintech, Small Business and the American Dream. New York: Springer.

Mitchell, Stacy and Susan R. Holmberg. 2020. "Why the Left Should Ally with Small Business." The Nation. https://www.thenation.com/article/society/democrats-labor-businessmonopoly/.

Mizruchi, Mark S. 2004. "Berle and Means Revisited: The Governance and Power of Large U.S. Corporations." Theory and Society 33(5): 579-617.

Morris, Martina and Bruce Western. 1999. "Inequality in Earnings at the Close of the Twentieth Century." Annual Review of Sociology 25:623-657.

Mudd, Shannon. 2013. "Bank Structure, Relationship Lending and Small Firm Access to Finance: A Cross-Country Investigation." Journal of Financial Services Research 44(2): $149-174$

Narter, Bart. 2009. "It Takes More Than a Village: The Decline of the Community Bank." Bank Accounting \& Finance 22(4): 49-52.

Nathan, Sara. 1997. "Scoring, Underwriting Software Being Linked to Spur Securitization" American Banker. 17 November. 10:1.

Nelson, Richard R. and Edmund S. Phelps. 1966. "Investment in Humans, Technological Diffusion, and Economic Growth." American Economic Review 56:69-75.

Nowatzki, Nadine R. 2012. "Wealth Inequality and Health." International Journal of Health Services 42:403-424.

Oppenheim, Sara. 1997a. "Show Me the Money, Not the Bank, Businesses Say." American Banker. 19 May. 1:3. 
Oppenheim, Sara. 1997b. "With Automation and Securitization, A Handshake Business Gets Plastic" American Banker. 12 May. 1:2.

Pernell, Kim. 2020. “Market Governance, Financial Innovation, and Financial Instability:

Lessons from Banks' Adoption of Shareholder Value Management.” Theory and Society 49:277-306.

Pernell, Kim, Jiwook Jung, and Frank Dobbin. 2017. “The Hazards of Expert Control: Chief Risk Officers and Risky Derivatives.” American Sociological Review 82:511-541.

Perrow, Charles. 2000. "Review of Socializing Capital: The Rise of the Large Industrial Corporation in America by William G. Roy." Theory and Society 29(2): 261-268.

Piketty, Thomas. 2014. Capital in the $21^{\text {st }}$ Century: Cambridge, MA: Harvard University Press. Popken, Ben and Andrew W. Lehren. 2020. "Release of PPP Loan Recipients' Data Reveals Troubling Patterns.” https://www.nbcnews.com/business/business-news/release-ppploan-recipients-data-reveals-troubling-patterns-n1249629.

Reagan, Ronald. 1983. "Remarks at the National Conference of the National Federation of Independent Business." https://www.reaganlibrary.gov/archives/speech/remarks-nationalconference-national-federation-independent-business.

Roy, William G. 1997. "Socializing Capital: The Rise of the Large Industrial Corporation in America.” Princeton, NJ: Princeton University Press.

Rubin, Donald B. 1987. Multiple Imputation for Nonresponse in Surveys. New York: J. Wiley and Sons.

Ruef, Martin and Michael Lounsbury. 2007. “The Sociology of Entrepreneurship.” Research in the Sociology of Organizations 25:1-29. 
Schumpeter, Joseph. 1934 [1911]. The Theory of Economic Development. Cambridge, MA: Harvard University Press.

Shane, Scott. 2013. "Why Americans Love Small Business." Entrepreneur Magazine. https://www.entrepreneur.com/article/226176.

Small Business Association. 2012. "Frequently Asked Questions about Small Businesses." https://www.sba.gov/sites/default/files/FAQ_Sept_2012.pdf

Smith, Matthew, Danny Yagan, Owen Zidar, and Eric Swick. 2019. "Capitalists in the Twentyfirst Century.” The Quarterly Journal of Economics 134:1675-1745.

Sorensen, Aage B. 2000. "Toward a Sounder Basis for Class Analysis.” American Journal of Sociology 105:1523-1558.

Steijvers, Tensie, Wim Voordeckers and Koen Vanhoof. 2010. "Collateral, Relationship Lending and Family Firms.” Small Business Economics 34:243-259.

Stigler, George J. 1983. The Organization of Industry. Chicago: University of Chicago Press. Strahan, Philip E. 2008. "Bank Structure and Lending: What We Do and Do Not Know." Pp. 107-132 in Handbook of Financial Intermediation and Banking, eds. A.W.A. Boot and A.V. Thakor. Amsterdam: Elsevier.

Talbot, Deborah. 2018. "OECD Report Puts Small Business at the Heart of Equality Strategies." Forbes. https://www.forbes.com/sites/deborahtalbot/2018/06/11/oecd-report-puts-smallbusiness-at-the-heart-of-equality-strategies/?sh=6225405a2ed3.

Thornton, Patricia H., Domingo Ribeiro-Soriano, and David Urbano. 2011. "Socio-cultural Factors and Entrepreneurial Activity.” International Small Business Journal 29:105-118.

Tomaskovic-Devey, Donald and Dustin Avent-Holt. 2019. Relational Inequalities: An Organizational Approach. New York: Oxford University Press. 
U.S. Bureau of Labor Statistics. 2020. "Business Employment Dynamics." https://www.bls.gov/bdm/.

Violante, Giovanni L. 2008. “Skill-Biased Technical Change.” In The New Palgrave Dictionary of Economics. London: Palgrave Macmillan.

Weber, Max. 2003 [1889]. The History of Commercial Partnerships in the Middle Ages. Lanham, MD: Rowman and Littlefield.

Wodtke, Geoffrey T. 2016. "Social Class and Income Inequality in the United States." American Journal of Sociology 121:1375-1415.

Wolf, Michael. 2012. "The New Era of Democratized Business.” Forbes. https://www.forbes.com/sites/michaelwolf/2012/11/05/the-new-era-of-democratizedbusiness/?sh=635e928f8dd1.

Wood, Simon N., Natalya Pya, and Benjamin Saefken. 2016. "Smoothing Parameter and Model Selection for General Smooth Models." Journal of the American Statistical Association 111:1548-1575.

Wooldridge, Jeffrey M. 2010. Econometric Analysis of Cross Section and Panel Data (2nd Edition). Cambridge, MA: MIT Press.

Yellen, Janet L. 2014. "Perspectives on Inequality and Opportunity from the Survey of Consumer Finances." Federal Reserve Bank of Boston.

Zucman, Gabriel. 2015. The Hidden Wealth of Nations. Chicago: University of Chicago Press. 


\section{FIGURES}

Total Population

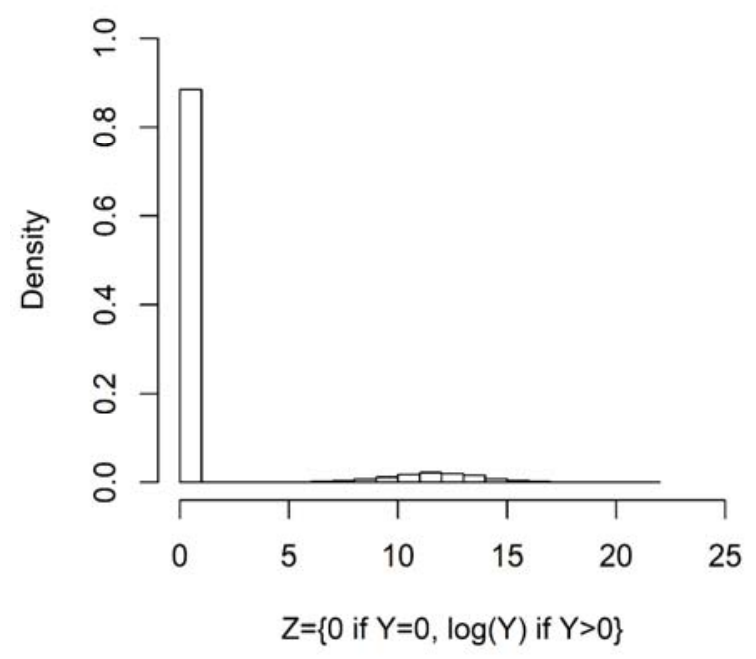

Business Owners

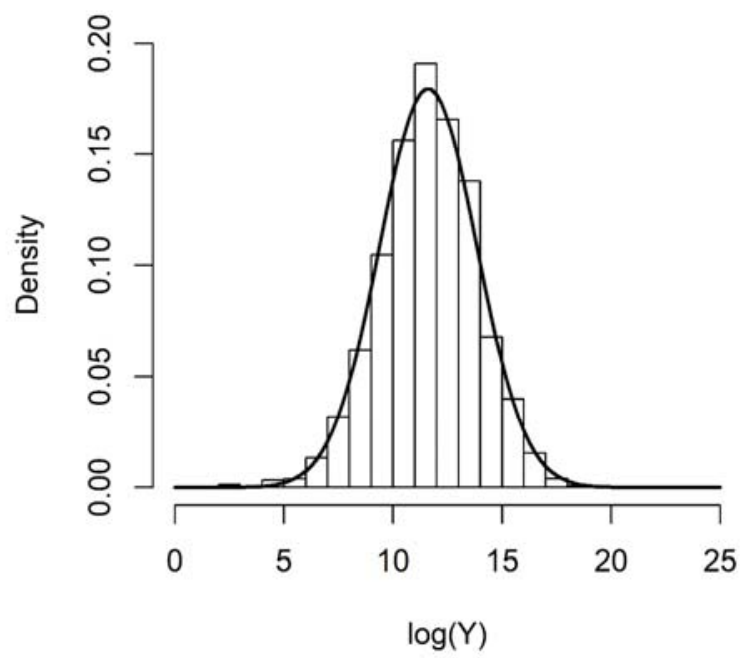

Figure 1. The Household Distribution of Privately Held Business Assets 

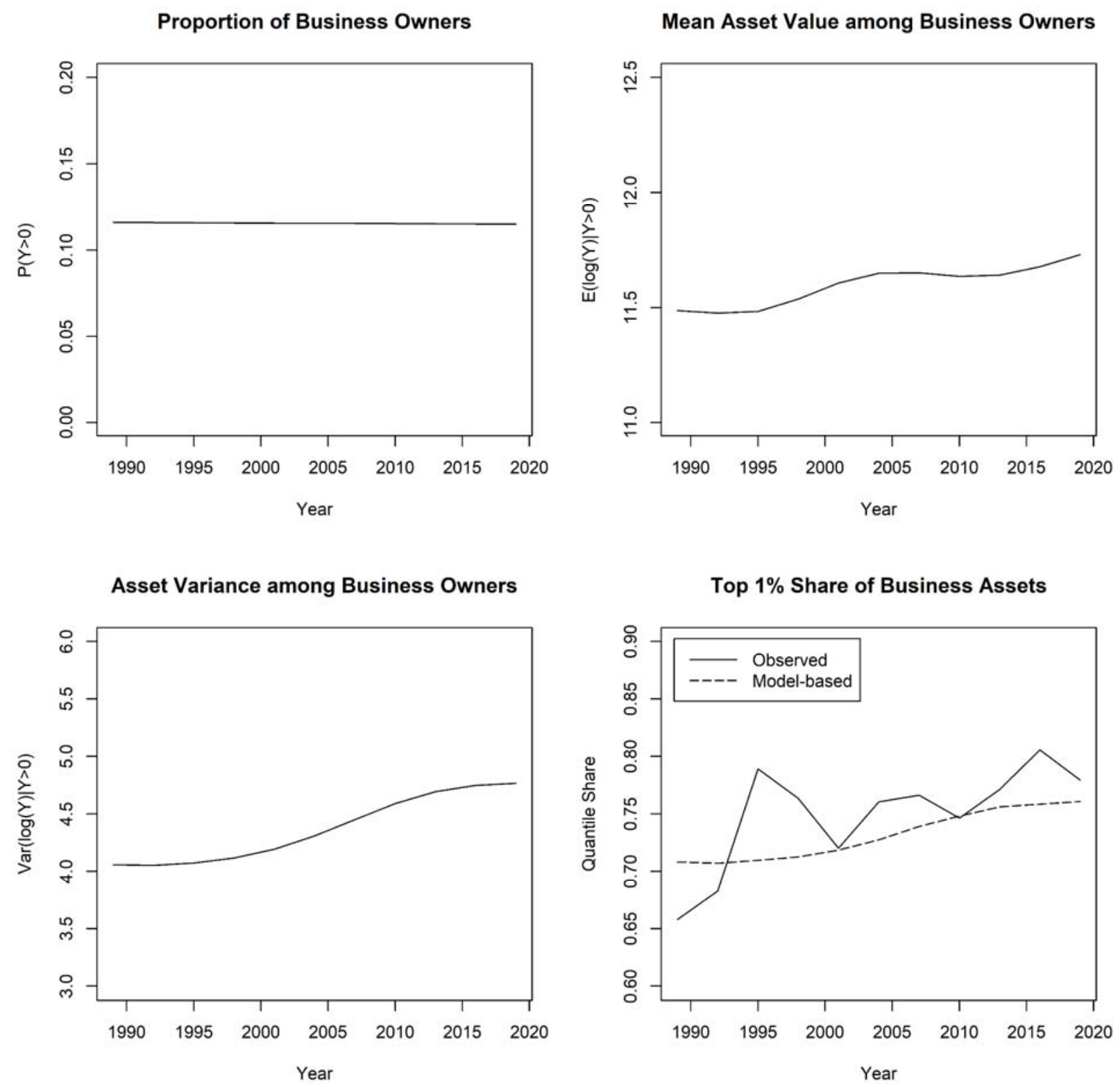

Figure 2. Trends in the Household Distribution of Privately Held Business Assets 
Educational Composition of Total Pop.

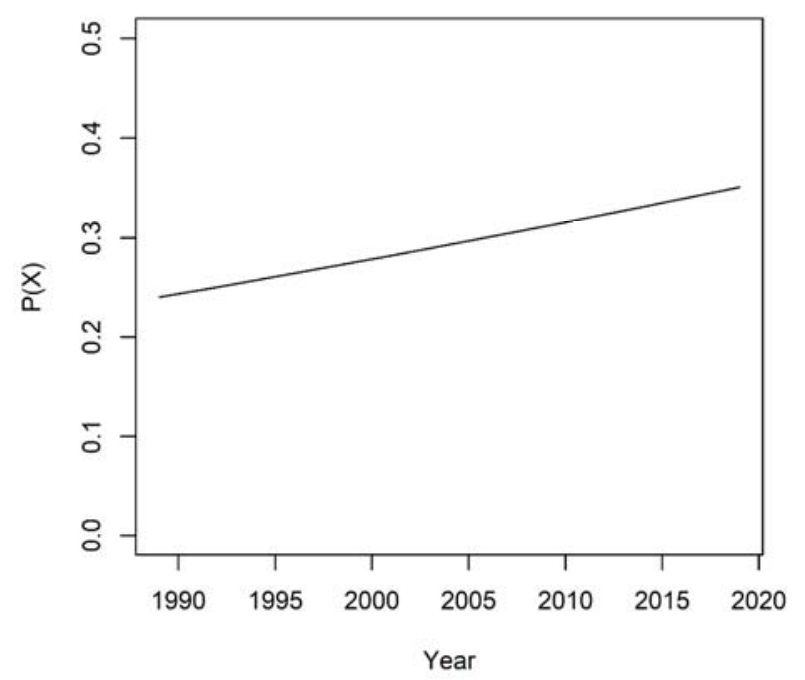

Mean Asset Value by Education

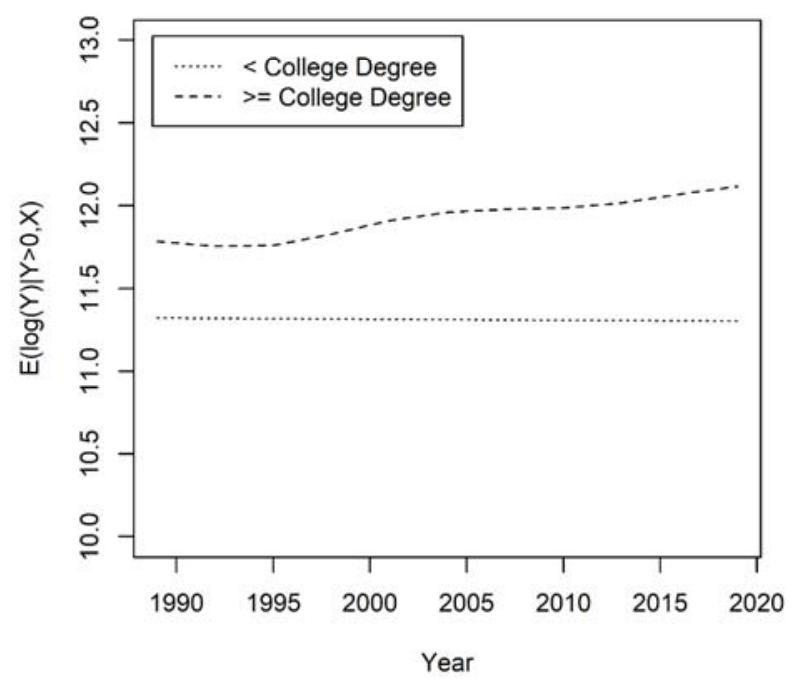

Business Ownership by Education

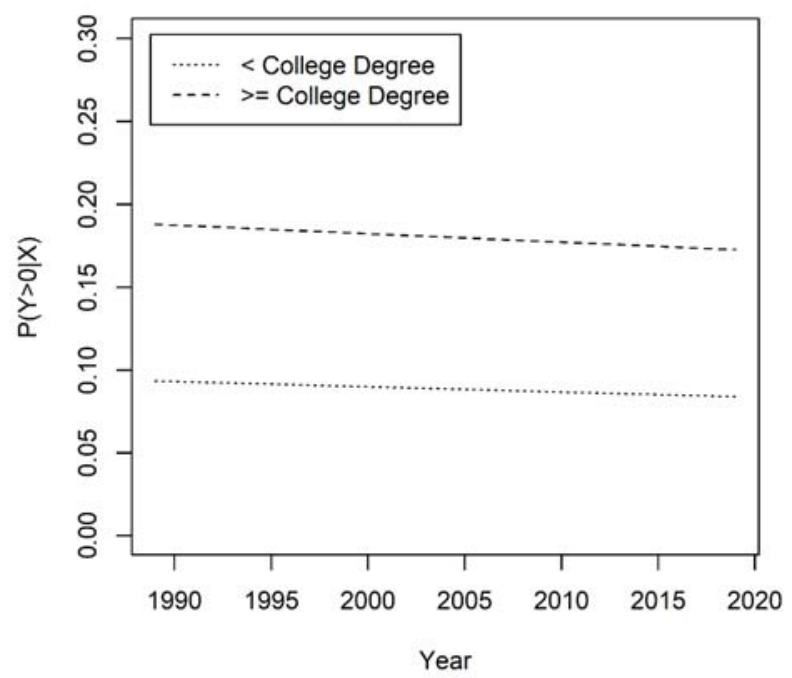

Asset Variance by Education

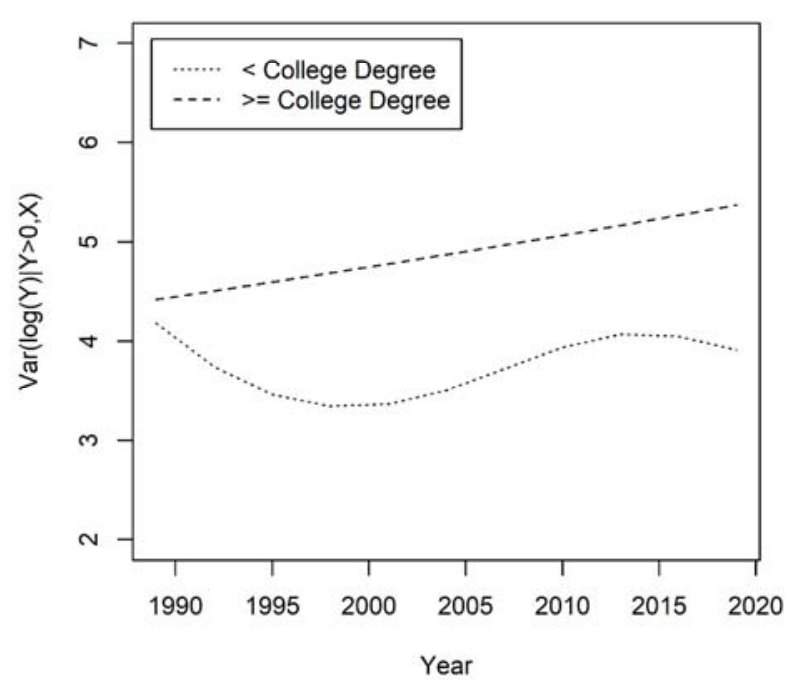

Figure 3. The Relationship of Education to the Household Distribution of Privately Held Business Assets 


\section{Counterfactual Differences in the Top $1 \%$ Share}

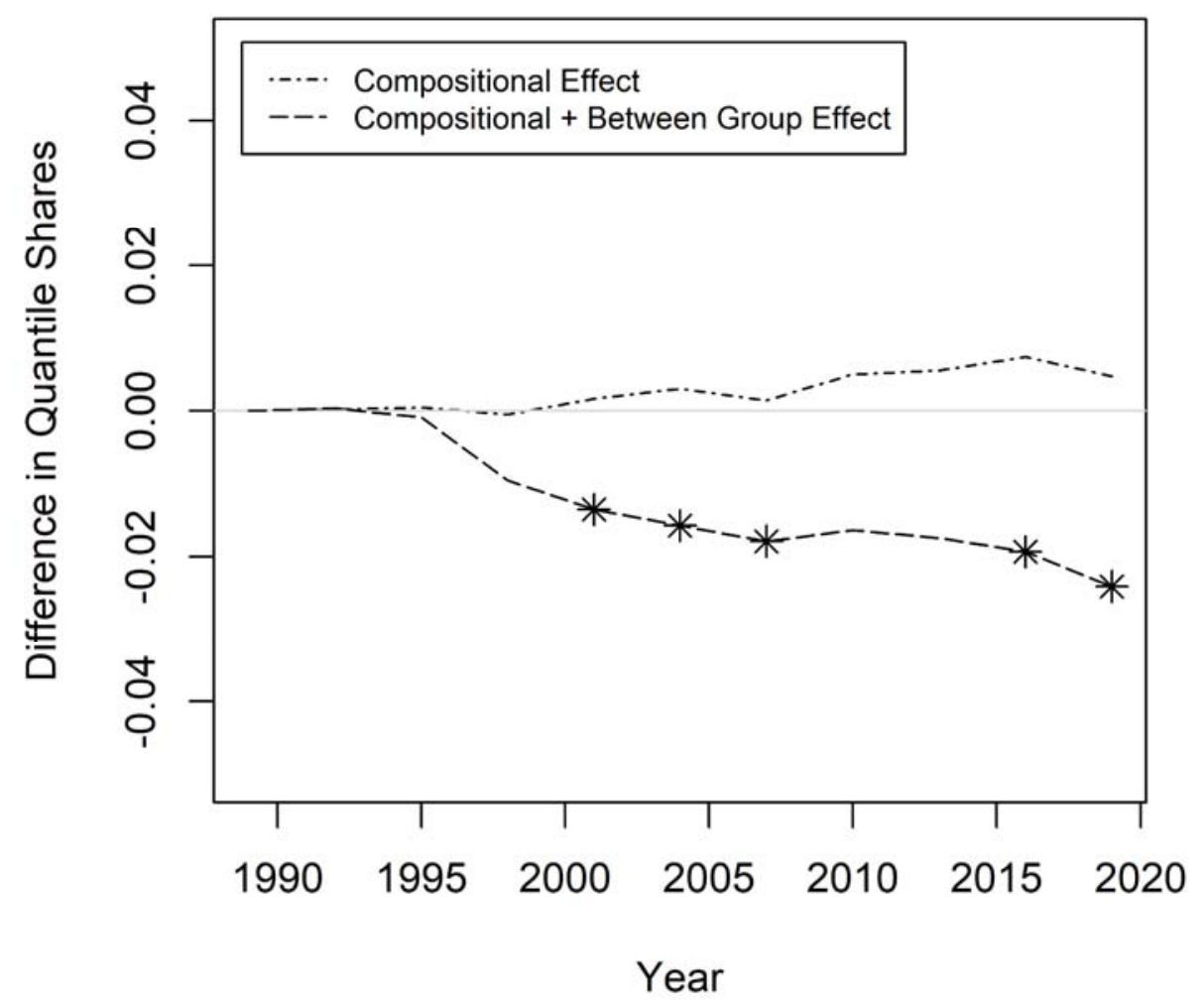

Figure 4. The Relationship of Education to Growth in the Concentration of Privately Held Business Assets

Note: Asterisks in this figure denote that $p<0.05$ from a bootstrap z-test of the null hypothesis that a counterfactual difference in top $1 \%$ shares is equal to zero. 
Credit Access among Business Owners

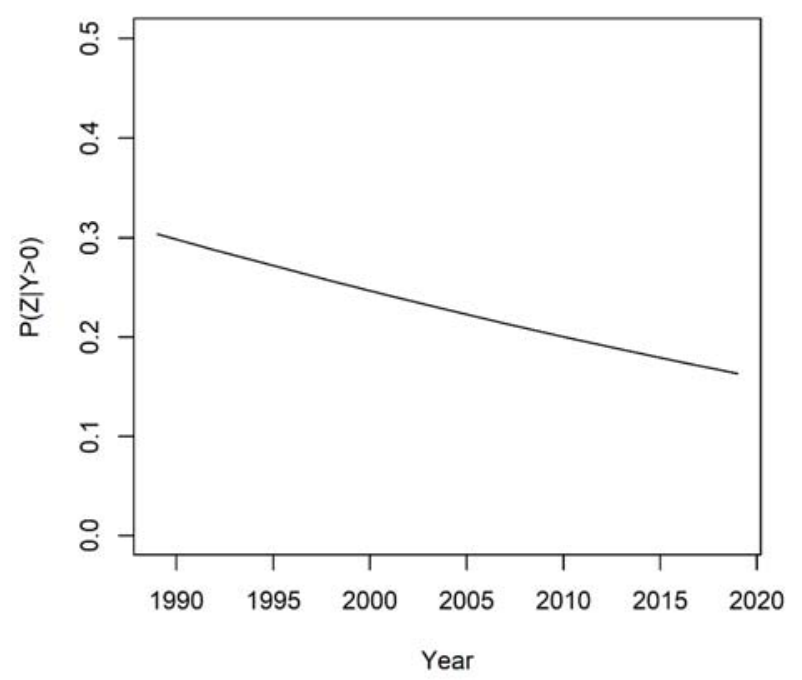

Asset Variance by Credit Access

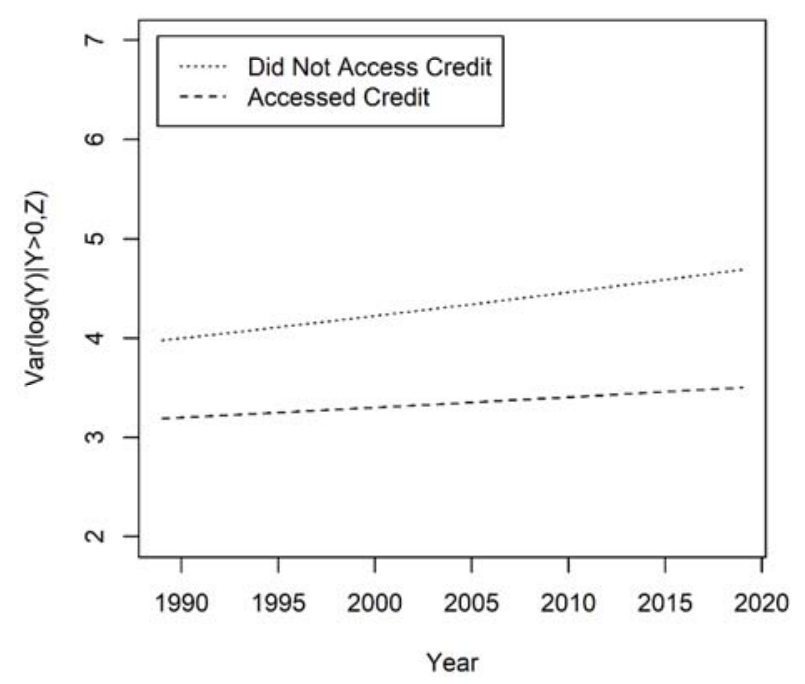

Mean Asset Value by Credit Access

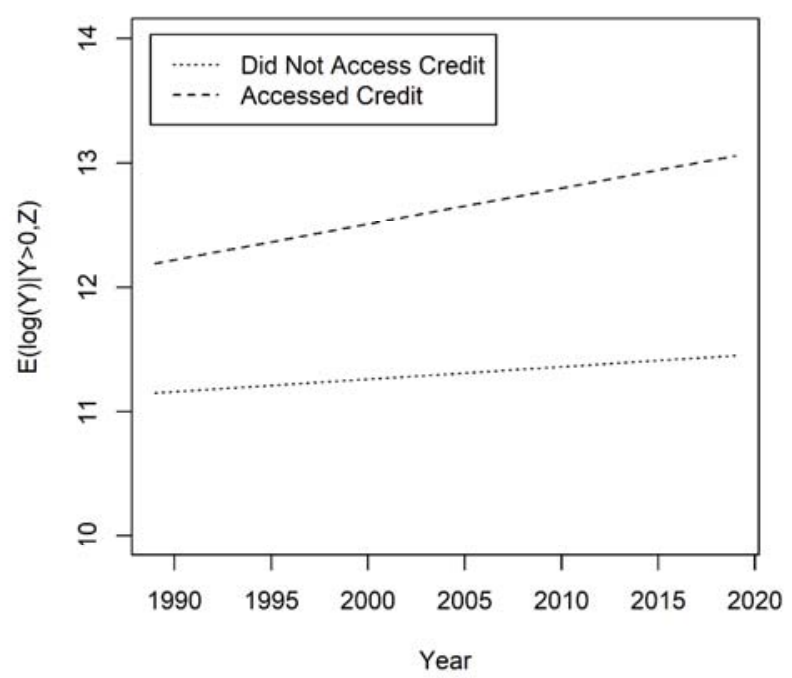

Counterfactual Differences in the Top $1 \%$ Share

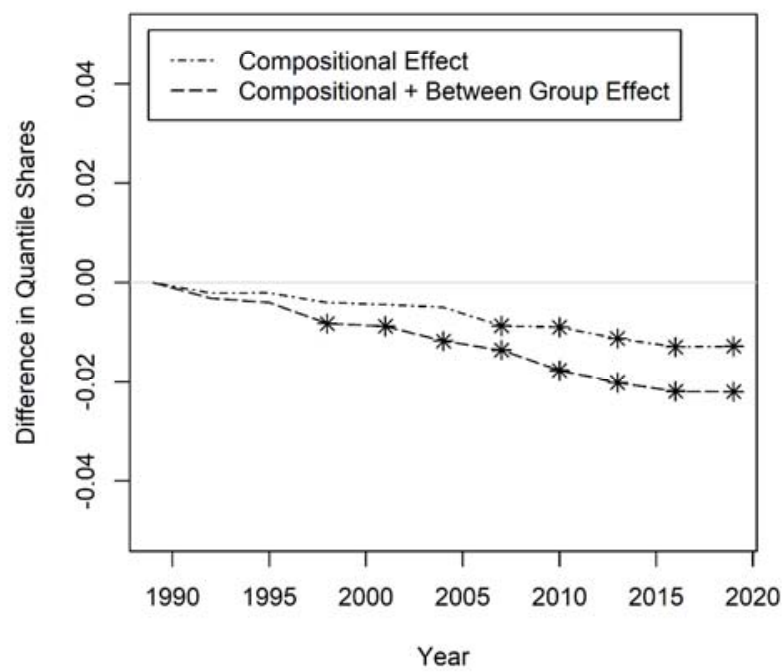

Figure 5. The Relationship of Credit Access to the Household Distribution of Privately Held Business Assets

Note: Asterisks in this figure denote that $p<0.05$ from a bootstrap z-test of the null hypothesis that a counterfactual difference in top $1 \%$ shares is equal to zero. 

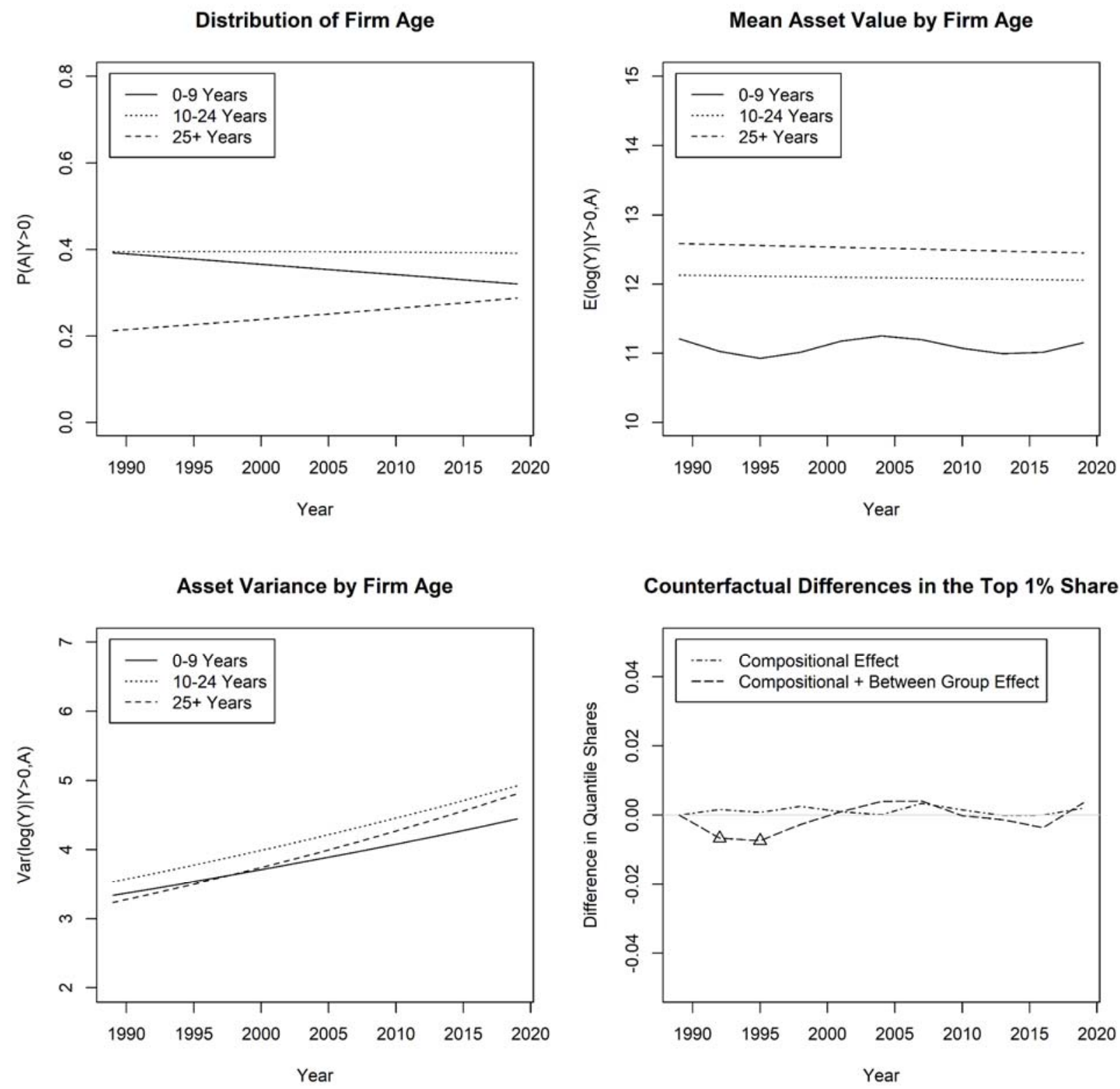

Figure 6. The Relationship of Firm Age to the Household Distribution of Privately Held Business Assets

Note: Asterisks in this figure denote that $p<0.05$ from a bootstrap z-test of the null hypothesis that a counterfactual difference in top $1 \%$ shares is equal to zero. Triangles denote that $0.05<$ $p<0.10$ from the same test. 

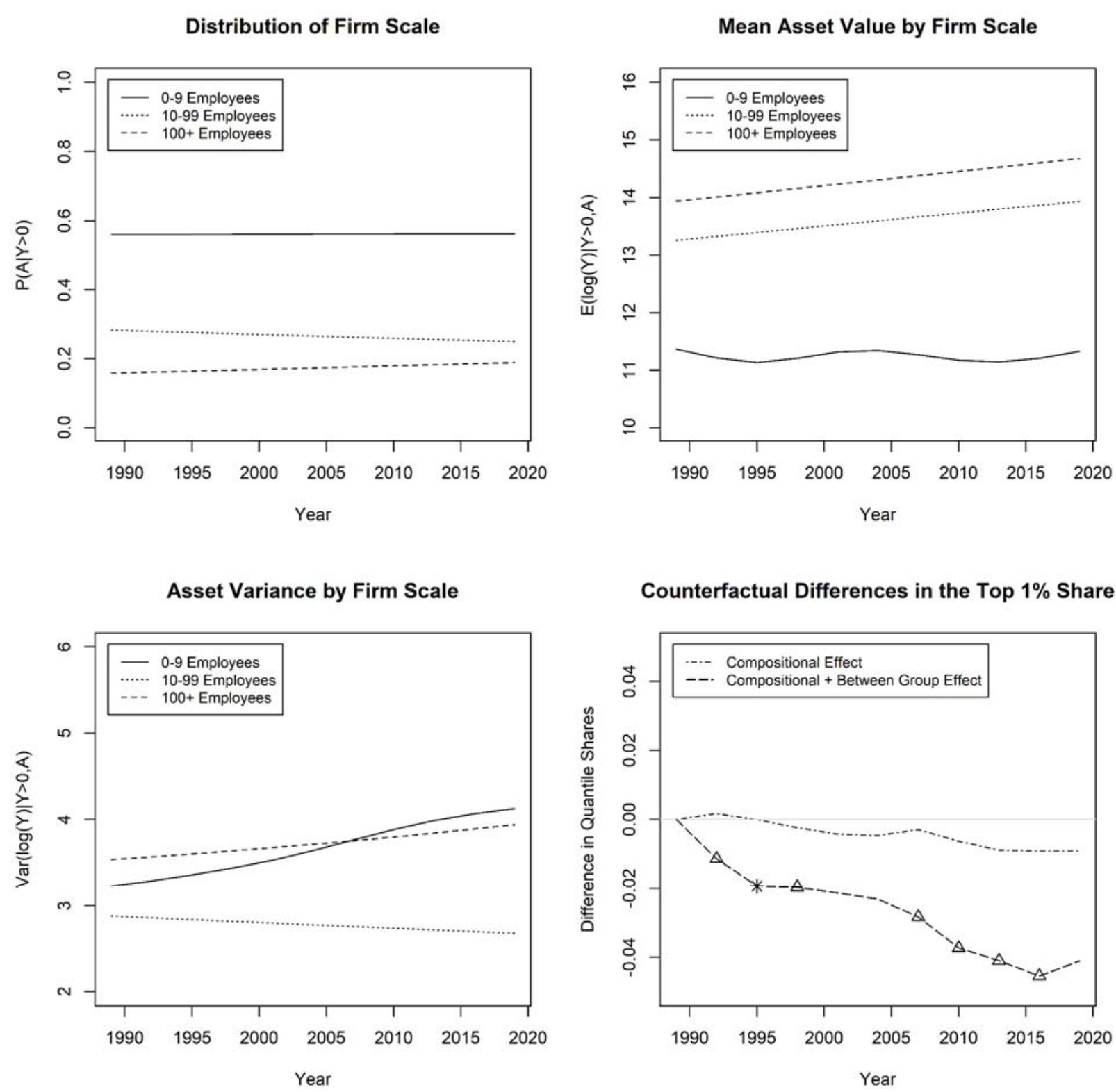

Figure 7. The Relationship of Firm Scale to the Household Distribution of Privately Held Business Assets

Note: Asterisks in this figure denote that $p<0.05$ from a bootstrap z-test of the null hypothesis that a counterfactual difference in top $1 \%$ share is equal to zero. Triangles denote that $0.05<$ $p<0.10$ from the same test. 


\section{TABLES}

Table 1. Hurdle Models for Trends in the Distribution of Privately Held Business Assets

\begin{tabular}{|c|c|c|c|c|c|c|c|c|c|}
\hline \multirow{2}{*}{ Estimand } & \multicolumn{3}{|c|}{$\Phi(\mathrm{P}(\mathrm{Y}>0))$} & \multicolumn{3}{|c|}{$\mathrm{E}(\log (\mathrm{Y}) \mid \mathrm{Y}>0)$} & \multicolumn{3}{|c|}{$\operatorname{Var}(\log (\mathrm{Y}) \mid \mathrm{Y}>0)$} \\
\hline & est. & se & p-value & est. & se & p-value & est. & se & p-value \\
\hline \multicolumn{10}{|l|}{ Linear Trend Model } \\
\hline intercept & -1.195 & 0.016 & $<0.001$ & 11.475 & 0.059 & $<0.001$ & 1.481 & 0.043 & $<0.001$ \\
\hline year & 0.000 & 0.001 & 1.000 & 0.008 & 0.003 & 0.008 & 0.007 & 0.002 & 0.003 \\
\hline \multicolumn{10}{|l|}{ AIC Fit Statistics } \\
\hline linear trend model & 34647 & - & - & 83275 & - & - & 29343 & - & - \\
\hline spline trend model & 34647 & - & - & 83275 & - & - & 29332 & - & - \\
\hline
\end{tabular}

Notes: Parameter estimates and standard errors are combined estimates from 5 imputations. Within each imputation, standard errors are computed using bootstrap replicate weights for complex survey designs. AIC values are computed using the weighted pseudo-likelihood from a single imputation. 
Table 2. Hurdle Models for the Relationship of Education to the Distribution of Privately Held Business Assets

\begin{tabular}{|c|c|c|c|c|c|c|c|c|c|}
\hline \multirow{2}{*}{ Estimand } & \multicolumn{3}{|c|}{$\Phi(\mathrm{P}(\mathrm{Y}>0))$} & \multicolumn{3}{|c|}{$\mathrm{E}(\log (\mathrm{Y}) \mid \mathrm{Y}>0)$} & \multicolumn{3}{|c|}{$\operatorname{Var}(\log (\mathrm{Y}) \mid \mathrm{Y}>0)$} \\
\hline & est. & se & $\mathrm{p}$-value & est. & se & p-value & est. & se & p-value \\
\hline \multicolumn{10}{|l|}{ Linear Trends Model } \\
\hline intercept & -1.319 & 0.018 & $<0.001$ & 11.321 & 0.073 & $<0.001$ & 1.388 & 0.068 & $<0.001$ \\
\hline year & -0.002 & 0.001 & 0.046 & -0.001 & 0.004 & 0.803 & 0.003 & 0.003 & 0.317 \\
\hline college graduate & 0.435 & 0.023 & $<0.001$ & 0.417 & 0.091 & $<0.001$ & 0.208 & 0.091 & 0.021 \\
\hline year $\mathrm{x}$ college graduate & 0.000 & 0.001 & 1.000 & 0.013 & 0.005 & 0.009 & 0.003 & 0.004 & 0.453 \\
\hline \multicolumn{10}{|l|}{ AIC Fit Statistics } \\
\hline linear trends by educ. model & 34070 & - & - & 82987 & - & - & 29092 & - & - \\
\hline spline trends by educ. model & 34070 & - & - & 82987 & - & - & 29068 & - & - \\
\hline
\end{tabular}

Notes: Parameter estimates and standard errors are combined estimates from 5 imputations. Within each imputation, standard errors are computed using bootstrap replicate weights for complex survey designs. AIC values are computed using the weighted pseudo-likelihood from a single imputation. 
Table 3. Conditional Mean and Variance Models for the Relationship of Credit Access to the Distribution of Privately Held Business Assets

\begin{tabular}{|c|c|c|c|c|c|c|}
\hline \multirow{2}{*}{ Estimand } & \multicolumn{3}{|c|}{$\mathrm{E}(\log (\mathrm{Y}) \mid \mathrm{Y}>0)$} & \multicolumn{3}{|c|}{$\operatorname{Var}(\log (Y) \mid Y>0)$} \\
\hline & est. & se & $\mathrm{p}$-value & est. & se & p-value \\
\hline \multicolumn{7}{|l|}{ Linear Trends Model } \\
\hline intercept & 11.150 & 0.062 & $<0.001$ & 1.486 & 0.049 & $<0.001$ \\
\hline year & 0.010 & 0.003 & 0.001 & 0.006 & 0.002 & 0.003 \\
\hline accessed credit & 1.043 & 0.089 & $<0.001$ & -0.220 & 0.067 & 0.001 \\
\hline year $\mathrm{x}$ accessed credit & 0.019 & 0.005 & $<0.001$ & -0.002 & 0.003 & 0.505 \\
\hline \multicolumn{7}{|l|}{ AIC Fit Statistics } \\
\hline linear trends by cred. model & 82368 & - & - & 28439 & - & - \\
\hline spline trends by cred. model & 82368 & - & - & 28439 & - & - \\
\hline
\end{tabular}

Notes: Parameter estimates and standard errors are combined estimates from 5 imputations. Within each imputation, standard errors are computed using bootstrap replicate weights for complex survey designs. AIC values are computed using the weighted pseudo-likelihood from a single imputation. 
Table 4. Conditional Mean and Variance Models for the Relationship of Firm Age and Firm Scale to the Distribution of Privately Held Business Assets

\begin{tabular}{|c|c|c|c|c|c|c|}
\hline \multirow{2}{*}{ Estimand } & \multicolumn{3}{|c|}{$\mathrm{E}(\log (\mathrm{Y}) \mid \mathrm{Y}>0)$} & \multicolumn{3}{|c|}{$\operatorname{Var}(\log (Y) \mid Y>0)$} \\
\hline & est. & se & p-value & est. & se & $\mathrm{p}$-value \\
\hline \multicolumn{7}{|l|}{ Linear Trends by Firm Age Model } \\
\hline intercept & 11.086 & 0.067 & $<0.001$ & 1.325 & 0.051 & $<0.001$ \\
\hline year & 0.000 & 0.003 & 1.000 & 0.009 & 0.003 & 0.003 \\
\hline \multicolumn{7}{|l|}{ firm age (ref: 0-9 years) } \\
\hline 10-24 years & 1.044 & 0.102 & $<0.001$ & 0.042 & 0.102 & 0.681 \\
\hline $25+$ years & 1.501 & 0.120 & $<0.001$ & -0.045 & 0.105 & 0.668 \\
\hline \multicolumn{7}{|l|}{ interactions } \\
\hline year $\mathrm{x}$ firm of 10-24 years & -0.003 & 0.005 & 0.549 & 0.002 & 0.005 & 0.689 \\
\hline year $\mathrm{x}$ firm of $25+$ years & -0.005 & 0.006 & 0.405 & 0.004 & 0.005 & 0.424 \\
\hline \multicolumn{7}{|l|}{ Linear Trends by Scale Model } \\
\hline intercept & 11.248 & 0.055 & $<0.001$ & 1.276 & 0.039 & $<0.001$ \\
\hline year & 0.000 & 0.003 & 1.000 & 0.009 & 0.002 & $<0.001$ \\
\hline \multicolumn{7}{|l|}{ firm scale (ref: 0-9 empl.) } \\
\hline 10-99 employees & 2.012 & 0.109 & $<0.001$ & -0.113 & 0.122 & 0.354 \\
\hline $100+$ employees & 2.691 & 0.277 & $<0.001$ & 0.079 & 0.239 & 0.741 \\
\hline \multicolumn{7}{|l|}{ interactions } \\
\hline year $x$ firm of 10-99 empl. & 0.023 & 0.006 & $<0.001$ & -0.011 & 0.006 & 0.067 \\
\hline year $x$ firm of $100+$ empl. & 0.025 & 0.014 & 0.074 & -0.005 & 0.011 & 0.649 \\
\hline \multicolumn{7}{|l|}{ AIC Fit Statistics } \\
\hline linear trends by firm age model & 73526 & - & - & 25982 & - & - \\
\hline spline trends by firm age model & 73492 & - & - & 25982 & - & - \\
\hline linear trends by scale model & 71983 & - & - & 24439 & - & - \\
\hline spline trends by scale model & 71945 & - & - & 24439 & - & - \\
\hline
\end{tabular}

Notes: Parameter estimates and standard errors are combined estimates from 5 imputations. Within each imputation, standard errors are computed using bootstrap replicate weights for complex survey designs. AIC values are computed using the weighted pseudo-likelihood from a single imputation. 


\section{ONLINE SUPPLEMENT}

\section{Part A: Parallel Analyses of Non-farm Business Assets}

Table A.1. Hurdle Models for Trends in the Distribution of Privately Held Non-Farm Business Assets

\begin{tabular}{|c|c|c|c|c|c|c|c|c|c|}
\hline \multirow{2}{*}{ Estimand } & \multicolumn{3}{|c|}{$\Phi(\mathrm{P}(\mathrm{Y}>0))$} & \multicolumn{3}{|c|}{$\mathrm{E}(\log (\mathrm{Y}) \mid \mathrm{Y}>0)$} & \multicolumn{3}{|c|}{$\operatorname{Var}(\log (Y) \mid Y>0)$} \\
\hline & est. & se & p-value & est. & se & p-value & est. & se & $\mathrm{p}$-value \\
\hline \multicolumn{10}{|l|}{ Linear Trend Model } \\
\hline intercept & -1.198 & 0.016 & $<0.001$ & 11.414 & 0.056 & $<0.001$ & 1.465 & 0.042 & $<0.001$ \\
\hline year & 0.000 & 0.001 & 1.000 & 0.008 & 0.003 & 0.008 & 0.007 & 0.002 & 0.003 \\
\hline \multicolumn{10}{|l|}{ AIC Fit Statistics } \\
\hline linear trend model & 34558 & - & - & 83091 & - & - & 28814 & - & - \\
\hline spline trend model & 34558 & - & - & 83058 & - & - & 28803 & - & - \\
\hline
\end{tabular}

Notes: Parameter estimates and standard errors are combined estimates from 5 imputations. Within each imputation, standard errors are computed using bootstrap replicate weights for complex survey designs. AIC values are computed using the weighted pseudo-likelihood from a single imputation. 
Table A.2. Hurdle Models for the Relationship of Education to the Distribution of Privately Held Non-Farm Business Assets

\begin{tabular}{|c|c|c|c|c|c|c|c|c|c|}
\hline \multirow{2}{*}{ Estimand } & \multicolumn{3}{|c|}{$\Phi(\mathrm{P}(\mathrm{Y}>0))$} & \multicolumn{3}{|c|}{$\mathrm{E}(\log (\mathrm{Y}) \mid \mathrm{Y}>0)$} & \multicolumn{3}{|c|}{$\operatorname{Var}(\log (\mathrm{Y}) \mid \mathrm{Y}>0)$} \\
\hline & est. & se & $\mathrm{p}$-value & est. & se & $\mathrm{p}$-value & est. & se & p-value \\
\hline \multicolumn{10}{|l|}{ Linear Trends Model } \\
\hline intercept & -1.325 & 0.018 & $<0.001$ & 11.228 & 0.069 & $<0.001$ & 1.352 & 0.067 & $<0.001$ \\
\hline year & -0.002 & 0.001 & 0.046 & -0.001 & 0.004 & 0.803 & 0.004 & 0.003 & 0.182 \\
\hline college graduate & 0.439 & 0.023 & $<0.001$ & 0.497 & 0.091 & $<0.001$ & 0.243 & 0.089 & 0.006 \\
\hline year $\mathrm{x}$ college graduate & 0.000 & 0.001 & 1.000 & 0.012 & 0.005 & 0.016 & 0.003 & 0.004 & 0.453 \\
\hline \multicolumn{10}{|l|}{ AIC Fit Statistics } \\
\hline linear trends by educ. model & 33974 & - & - & 82735 & - & - & 28784 & - & - \\
\hline spline trends by educ. model & 33974 & - & - & 82735 & - & - & 28760 & - & - \\
\hline
\end{tabular}

Notes: Parameter estimates and standard errors are combined estimates from 5 imputations. Within each imputation, standard errors are computed using bootstrap replicate weights for complex survey designs. AIC values are computed using the weighted pseudo-likelihood from a single imputation. 
Table A.3. Conditional Mean and Variance Models for the Relationship of Credit Access to the Distribution of Privately Held Non-Farm Business Assets

\begin{tabular}{|c|c|c|c|c|c|c|}
\hline \multirow{2}{*}{ Estimand } & \multicolumn{3}{|c|}{$\mathrm{E}(\log (\mathrm{Y}) \mid \mathrm{Y}>0)$} & \multicolumn{3}{|c|}{$\operatorname{Var}(\log (Y) \mid Y>0)$} \\
\hline & est. & $\mathrm{se}$ & $\mathrm{p}$-value & est. & se & p-value \\
\hline \multicolumn{7}{|l|}{ Linear Trends Model } \\
\hline intercept & 11.084 & 0.059 & $<0.001$ & 1.466 & 0.049 & $<0.001$ \\
\hline year & 0.010 & 0.003 & 0.001 & 0.006 & 0.002 & 0.003 \\
\hline accessed credit & 1.055 & 0.087 & $<0.001$ & -0.214 & 0.067 & 0.001 \\
\hline year $\mathrm{x}$ accessed credit & 0.020 & 0.005 & $<0.001$ & -0.003 & 0.003 & 0.317 \\
\hline \multicolumn{7}{|l|}{ AIC Fit Statistics } \\
\hline linear trends by cred. model & 82132 & - & - & 28131 & - & . \\
\hline spline trends by cred. model & 82132 & - & - & 28131 & - & - \\
\hline
\end{tabular}

Notes: Parameter estimates and standard errors are combined estimates from 5 imputations. Within each imputation, standard errors are computed using bootstrap replicate weights for complex survey designs. AIC values are computed using the weighted pseudo-likelihood from a single imputation. 
Table A.4. Conditional Mean and Variance Models for the Relationship of Firm Scale to the Distribution of Privately Held Non-Farm Business Assets

\begin{tabular}{|c|c|c|c|c|c|c|}
\hline \multirow{2}{*}{ Estimand } & \multicolumn{3}{|c|}{$\mathrm{E}(\log (\mathrm{Y}) \mid \mathrm{Y}>0)$} & \multicolumn{3}{|c|}{$\operatorname{Var}(\log (Y) \mid Y>0)$} \\
\hline & est. & se & p-value & est. & se & p-value \\
\hline \multicolumn{7}{|l|}{ Linear Trends by Scale Model } \\
\hline intercept & 11.168 & 0.051 & $<0.001$ & 1.239 & 0.038 & $<0.001$ \\
\hline year & -0.001 & 0.003 & 0.739 & 0.010 & 0.002 & $<0.001$ \\
\hline \multicolumn{7}{|l|}{ firm scale (ref: 0-9 empl.) } \\
\hline 10-99 employees & 2.083 & 0.109 & $<0.001$ & -0.075 & 0.121 & 0.535 \\
\hline $100+$ employees & 2.766 & 0.275 & $<0.001$ & 0.113 & 0.240 & 0.638 \\
\hline \multicolumn{7}{|l|}{ interactions } \\
\hline year x firm of 10-99 empl. & 0.023 & 0.006 & $<0.001$ & -0.012 & 0.006 & 0.046 \\
\hline year x firm of $100+$ empl. & 0.025 & 0.014 & 0.074 & -0.005 & 0.011 & 0.649 \\
\hline \multicolumn{7}{|l|}{ AIC Fit Statistics } \\
\hline linear trends by scale model & 71639 & - & - & 23974 & - & - \\
\hline spline trends by scale model & 71591 & - & - & 23974 & - & - \\
\hline
\end{tabular}

Notes: Parameter estimates and standard errors are combined estimates from 5 imputations. Within each imputation, standard errors are computed using bootstrap replicate weights for complex survey designs. AIC values are computed using the weighted pseudo-likelihood from a single imputation. 


\section{Part B: Parallel Analyses of a Business Asset Measure Augmented via Income Capitalization}

Table B.1. Hurdle Models for Trends in the Distribution of Privately Held Business Assets Augmented via Income Capitalization

\begin{tabular}{|c|c|c|c|c|c|c|c|c|c|}
\hline \multirow{2}{*}{ Estimand } & \multicolumn{3}{|c|}{$\Phi(\mathrm{P}(\mathrm{Y}>0))$} & \multicolumn{3}{|c|}{$\mathrm{E}(\log (\mathrm{Y}) \mid \mathrm{Y}>0)$} & \multicolumn{3}{|c|}{$\operatorname{Var}(\log (\mathrm{Y}) \mid \mathrm{Y}>0)$} \\
\hline & est. & se & $\mathrm{p}$-value & est. & se & $\mathrm{p}$-value & est. & se & $\mathrm{p}$-value \\
\hline \multicolumn{10}{|l|}{ Linear Trend Model } \\
\hline intercept & -1.195 & 0.016 & $<0.001$ & 11.431 & 0.054 & $<0.001$ & 1.547 & 0.048 & $<0.001$ \\
\hline year & 0.000 & 0.001 & 1.000 & 0.030 & 0.003 & $<0.001$ & 0.001 & 0.002 & 0.617 \\
\hline \multicolumn{10}{|l|}{ AIC Fit Statistics } \\
\hline linear trend model & 34647 & - & - & 82834 & - & - & 28852 & - & - \\
\hline spline trend model & 34647 & - & - & 82834 & - & - & 28852 & - & - \\
\hline
\end{tabular}

Notes: Parameter estimates and standard errors are combined estimates from 5 imputations. Within each imputation, standard errors are computed using bootstrap replicate weights for complex survey designs. AIC values are computed using the weighted pseudo-likelihood from a single imputation. 
Table B.2. Hurdle Models for the Relationship of Education to the Distribution of Privately Held Business Assets Augmented via Income Capitalization

\begin{tabular}{|c|c|c|c|c|c|c|c|c|c|}
\hline \multirow{2}{*}{ Estimand } & \multicolumn{3}{|c|}{$\Phi(\mathrm{P}(\mathrm{Y}>0))$} & \multicolumn{3}{|c|}{$\mathrm{E}(\log (\mathrm{Y}) \mid \mathrm{Y}>0)$} & \multicolumn{3}{|c|}{$\operatorname{Var}(\log (Y) \mid Y>0)$} \\
\hline & est. & se & p-value & est. & se & $\mathrm{p}$-value & est. & se & $\mathrm{p}$-value \\
\hline \multicolumn{10}{|l|}{ Linear Trends Model } \\
\hline intercept & -1.319 & 0.018 & $<0.001$ & 11.198 & 0.067 & $<0.001$ & 1.396 & 0.085 & $<0.001$ \\
\hline year & -0.002 & 0.001 & 0.046 & 0.024 & 0.003 & $<0.001$ & -0.003 & 0.004 & 0.453 \\
\hline college graduate & 0.435 & 0.023 & $<0.001$ & 0.611 & 0.086 & $<0.001$ & 0.314 & 0.102 & 0.002 \\
\hline year $\mathrm{x}$ college graduate & 0.000 & 0.001 & 1.000 & 0.006 & 0.004 & 0.134 & 0.003 & 0.005 & 0.549 \\
\hline \multicolumn{10}{|l|}{ AIC Fit Statistics } \\
\hline linear trends by educ. model & 34069 & - & - & 82460 & - & - & 28560 & - & - \\
\hline spline trends by educ. model & 34069 & - & - & 82460 & - & - & 28556 & - & - \\
\hline
\end{tabular}

Notes: Parameter estimates and standard errors are combined estimates from 5 imputations. Within each imputation, standard errors are computed using bootstrap replicate weights for complex survey designs. AIC values are computed using the weighted pseudo-likelihood from a single imputation. 
Table B.3. Conditional Mean and Variance Models for the Relationship of Credit Access to the Distribution of Privately Held Business Assets Augmented via Income Capitalization

\begin{tabular}{|c|c|c|c|c|c|c|}
\hline \multirow{2}{*}{ Estimand } & \multicolumn{3}{|c|}{$\mathrm{E}(\log (\mathrm{Y}) \mid \mathrm{Y}>0)$} & \multicolumn{3}{|c|}{$\operatorname{Var}(\log (\mathrm{Y}) \mid \mathrm{Y}>0)$} \\
\hline & est. & se & $\mathrm{p}$-value & est. & se & p-value \\
\hline \multicolumn{7}{|l|}{ Linear Trends Model } \\
\hline intercept & 11.157 & 0.062 & $<0.001$ & 1.563 & 0.058 & $<0.001$ \\
\hline year & 0.032 & 0.003 & $<0.001$ & 0.000 & 0.003 & 1.000 \\
\hline accessed credit & 0.883 & 0.092 & $<0.001$ & -0.182 & 0.076 & 0.017 \\
\hline year $\mathrm{x}$ accessed credit & 0.014 & 0.005 & 0.005 & -0.002 & 0.004 & 0.617 \\
\hline \multicolumn{7}{|l|}{ AIC Fit Statistics } \\
\hline linear trends by cred. model & 82185 & - & - & 28158 & - & - \\
\hline spline trends by cred. model & 82185 & - & - & 28158 & - & - \\
\hline
\end{tabular}

Notes: Parameter estimates and standard errors are combined estimates from 5 imputations. Within each imputation, standard errors are computed using bootstrap replicate weights for complex survey designs. AIC values are computed using the weighted pseudo-likelihood from a single imputation. 
Table B.4. Conditional Mean and Variance Models for the Relationship of Firm Scale to the Distribution of Privately held Business Assets Augmented via Income Capitalization

\begin{tabular}{|c|c|c|c|c|c|c|}
\hline \multirow{2}{*}{ Estimand } & \multicolumn{3}{|c|}{$\mathrm{E}(\log (\mathrm{Y}) \mid \mathrm{Y}>0)$} & \multicolumn{3}{|c|}{$\operatorname{Var}(\log (Y) \mid Y>0)$} \\
\hline & est. & se & $\mathrm{p}$-value & est. & se & $\mathrm{p}$-value \\
\hline \multicolumn{7}{|l|}{ Linear Trends by Scale Model } \\
\hline intercept & 11.163 & 0.048 & $<0.001$ & 1.318 & 0.038 & $<0.001$ \\
\hline year & 0.025 & 0.002 & 0.000 & 0.003 & 0.002 & 0.134 \\
\hline \multicolumn{7}{|l|}{ firm scale (ref: 0-9 empl.) } \\
\hline 10-99 employees & 1.984 & 0.102 & $<0.001$ & -0.020 & 0.114 & 0.861 \\
\hline $100+$ employees & 2.950 & 0.211 & $<0.001$ & -0.081 & 0.142 & 0.568 \\
\hline \multicolumn{7}{|l|}{ interactions } \\
\hline year $x$ firm of 10-99 empl. & 0.014 & 0.005 & 0.005 & -0.016 & 0.006 & 0.008 \\
\hline year x firm of $100+$ empl. & 0.028 & 0.011 & 0.011 & -0.010 & 0.010 & 0.317 \\
\hline
\end{tabular}

\section{AIC Fit Statistics}

$\begin{array}{llllll}\text { linear trends by scale model } & 71310 & - & - & 23715 & - \\ \text { spline trends by scale model } & 71252 & - & - & 23707 & -\end{array}$

Notes: Parameter estimates and standard errors are combined estimates from 5 imputations. Within each imputation, standard errors are computed using bootstrap replicate weights for complex survey designs. AIC values are computed using the weighted pseudo-likelihood from a single imputation. 


\section{Part C: Parallel Analyses based on a Measure of Personally Secured Bank Loans}

Table C.1. Conditional Mean and Variance Models for the Relationship of Personally Secured Bank Loan Use to the Distribution of Privately Held Business Assets

\begin{tabular}{|c|c|c|c|c|c|c|}
\hline \multirow{2}{*}{ Estimand } & \multicolumn{3}{|c|}{$\mathrm{E}(\log (\mathrm{Y}) \mid \mathrm{Y}>0)$} & \multicolumn{3}{|c|}{$\operatorname{Var}(\log (Y) \mid Y>0)$} \\
\hline & est. & se & p-value & est. & se & $\mathrm{p}$-value \\
\hline \multicolumn{7}{|l|}{ Linear Trends Model } \\
\hline intercept & 11.186 & 0.061 & $<0.001$ & 1.481 & 0.058 & $<0.001$ \\
\hline year & 0.010 & 0.003 & 0.001 & 0.006 & 0.002 & 0.003 \\
\hline accessed bank loan & 1.089 & 0.098 & $<0.001$ & -0.240 & 0.075 & 0.001 \\
\hline year $\mathrm{x}$ accessed bank loan & 0.020 & 0.005 & $<0.001$ & -0.003 & 0.004 & 0.453 \\
\hline \multicolumn{7}{|l|}{ AIC Fit Statistics } \\
\hline linear trends by loan model & 82298 & - & - & 28210 & - & - \\
\hline spline trends by loan model & 82298 & - & - & 28200 & - & - \\
\hline
\end{tabular}

Notes: Parameter estimates and standard errors are combined estimates from 5 imputations. Within each imputation, standard errors are computed using bootstrap replicate weights for complex survey designs. AIC values are computed using the weighted pseudo-likelihood from a single imputation. 
Part D: Trends in the Household Distribution of Private Business Assets by Industry, Occupation, and SME Classification

Table D.1. Hurdle Models for the Distribution of Privately Held Business Assets by Industry

\begin{tabular}{|c|c|c|c|c|c|c|c|c|c|}
\hline \multirow{2}{*}{ Estimand } & \multicolumn{3}{|c|}{$\Phi(\mathrm{P}(\mathrm{Y}>0))$} & \multicolumn{3}{|c|}{$\mathrm{E}(\log (\mathrm{Y}) \mid \mathrm{Y}>0)$} & \multicolumn{3}{|c|}{$\operatorname{Var}(\log (Y) \mid Y>0)$} \\
\hline & est. & se & $\mathrm{p}$-value & est. & se & $\mathrm{p}$-value & est. & se & $\mathrm{p}$-value \\
\hline \multicolumn{10}{|l|}{ Linear Trends Model } \\
\hline intercept & -1.230 & 0.017 & $<0.001$ & 11.538 & 0.060 & $<0.001$ & 1.490 & 0.043 & $<0.001$ \\
\hline year & -0.001 & 0.001 & 0.317 & 0.007 & 0.003 & 0.020 & 0.007 & 0.002 & $<0.001$ \\
\hline goods-producing industry & 0.146 & 0.029 & $<0.001$ & -0.247 & 0.110 & 0.025 & -0.039 & 0.125 & 0.755 \\
\hline year x goods-producing & 0.004 & 0.001 & $<0.001$ & 0.003 & 0.006 & 0.617 & -0.004 & 0.006 & 0.505 \\
\hline \multicolumn{10}{|l|}{ AIC Fit Statistics } \\
\hline linear trends by indus. model & 34487 & - & - & 83255 & - & - & 29124 & - & - \\
\hline spline trends by indus. model & 34065 & - & - & 82994 & - & - & 29075 & - & - \\
\hline
\end{tabular}

Notes: Parameter estimates and standard errors are combined estimates from 5 imputations. Within each imputation, standard errors are computed using bootstrap replicate weights for complex survey designs. AIC values are computed using the weighted pseudo-likelihood from a single imputation. 
Table D.2. Hurdle Models for the Distribution of Privately Held Business Assets by Occupation of Household Head

\begin{tabular}{|c|c|c|c|c|c|c|c|c|c|}
\hline \multirow{2}{*}{ Estimand } & \multicolumn{3}{|c|}{$\Phi(\mathrm{P}(\mathrm{Y}>0))$} & \multicolumn{3}{|c|}{$\mathrm{E}(\log (\mathrm{Y}) \mid \mathrm{Y}>0)$} & \multicolumn{3}{|c|}{$\operatorname{Var}(\log (\mathrm{Y}) \mid \mathrm{Y}>0)$} \\
\hline & est. & se & $\mathrm{p}$-value & est. & se & p-value & est. & se & p-value \\
\hline \multicolumn{10}{|l|}{ Linear Trends Model } \\
\hline intercept & -1.359 & 0.018 & $<0.001$ & 11.205 & 0.063 & $<0.001$ & 1.368 & 0.065 & $<0.001$ \\
\hline year & -0.004 & 0.001 & $<0.001$ & 0.002 & 0.003 & 0.505 & 0.006 & 0.003 & 0.046 \\
\hline prof/mgr occupation & 0.600 & 0.027 & $<0.001$ & 0.655 & 0.076 & $<0.001$ & 0.203 & 0.082 & 0.013 \\
\hline year $\mathrm{x}$ prof/mgr occ. & 0.003 & 0.001 & 0.003 & 0.004 & 0.004 & 0.317 & -0.001 & 0.004 & 0.803 \\
\hline \multicolumn{10}{|l|}{ AIC Fit Statistics } \\
\hline linear trends by occ. model & 33167 & - & - & 82898 & - & - & 28869 & - & - \\
\hline spline trends by occ. model & 33119 & - & - & 82785 & - & - & 28828 & - & - \\
\hline
\end{tabular}

Notes: Parameter estimates and standard errors are combined estimates from 5 imputations. Within each imputation, standard errors are computed using bootstrap replicate weights for complex survey designs. AIC values are computed using the weighted pseudo-likelihood from a single imputation. 
Table D.3. Hurdle Models for Trends in the Distribution of Privately Held Business Assets Including Only Small- and Medium-sized Enterprises (SMEs)

\begin{tabular}{|c|c|c|c|c|c|c|c|c|c|}
\hline \multirow{2}{*}{ Estimand } & \multicolumn{3}{|c|}{$\Phi(\mathrm{P}(\mathrm{Y}>0))$} & \multicolumn{3}{|c|}{$\mathrm{E}(\log (\mathrm{Y}) \mid \mathrm{Y}>0)$} & \multicolumn{3}{|c|}{$\operatorname{Var}(\log (\mathrm{Y}) \mid \mathrm{Y}>0)$} \\
\hline & est. & se & p-value & est. & se & p-value & est. & se & p-value \\
\hline \multicolumn{10}{|l|}{ Linear Trend Model } \\
\hline intercept & -1.196 & 0.016 & $<0.001$ & 11.466 & 0.059 & $<0.001$ & 1.475 & 0.043 & $<0.001$ \\
\hline year & 0.000 & 0.001 & 1.000 & 0.008 & 0.003 & 0.008 & 0.006 & 0.002 & 0.003 \\
\hline \multicolumn{10}{|l|}{ AIC Fit Statistics } \\
\hline linear trend model & 34594 & - & - & 77865 & - & - & 29067 & - & - \\
\hline spline trend model & 34594 & - & - & 77865 & - & - & 29057 & - & - \\
\hline
\end{tabular}

Notes: Parameter estimates and standard errors are combined estimates from 5 imputations. Within each imputation, standard errors are computed using bootstrap replicate weights for complex survey designs. AIC values are computed using the weighted pseudo-likelihood from a single imputation. SMEs are defined as private firms with fewer than 500 employees. 
Table D.4. Hurdle Models for Trends in the Distribution of Actively Managed Private Business Assets

\begin{tabular}{|c|c|c|c|c|c|c|c|c|c|}
\hline \multirow{2}{*}{ Estimand } & \multicolumn{3}{|c|}{$\Phi(\mathrm{P}(\mathrm{Y}>0))$} & \multicolumn{3}{|c|}{$\mathrm{E}(\log (\mathrm{Y}) \mid \mathrm{Y}>0)$} & \multicolumn{3}{|c|}{$\operatorname{Var}(\log (\mathrm{Y}) \mid \mathrm{Y}>0)$} \\
\hline & est. & se & p-value & est. & se & p-value & est. & se & p-value \\
\hline \multicolumn{10}{|l|}{ Linear Trend Model } \\
\hline intercept & -1.256 & 0.015 & $<0.001$ & 11.554 & 0.054 & $<0.001$ & 1.405 & 0.034 & $<0.001$ \\
\hline year & 0.000 & 0.001 & 1.000 & 0.003 & 0.003 & 0.317 & 0.010 & 0.002 & $<0.001$ \\
\hline \multicolumn{10}{|l|}{ AIC Fit Statistics } \\
\hline linear trend model & 32669 & - & - & 73580 & - & - & 26450 & - & - \\
\hline spline trend model & 32669 & - & - & 73534 & - & - & 26450 & - & - \\
\hline
\end{tabular}

Notes: Parameter estimates and standard errors are combined estimates from 5 imputations. Within each imputation, standard errors are computed using bootstrap replicate weights for complex survey designs. AIC values are computed using the weighted pseudo-likelihood from a single imputation. 
Part E: Partial Effects of Education, Credit Access, and Firm Scale on Business Assets

Table E.1. Conditional Mean and Variance Models for the Relationship of Education, Credit Access, and Firm Scale to the Distribution of Privately Held Business Assets

\begin{tabular}{|c|c|c|c|c|c|c|}
\hline \multirow{2}{*}{ Estimand } & \multicolumn{3}{|c|}{$\mathrm{E}(\log (\mathrm{Y}) \mid \mathrm{Y}>0)$} & \multicolumn{3}{|c|}{$\operatorname{Var}(\log (Y) \mid Y>0)$} \\
\hline & est. & se & $\mathrm{p}$-value & est. & se & p-value \\
\hline \multicolumn{7}{|l|}{ Linear Trends Model } \\
\hline intercept & 10.991 & 0.063 & $<0.001$ & 1.230 & 0.064 & $<0.001$ \\
\hline year & -0.005 & 0.003 & 0.096 & 0.004 & 0.003 & 0.182 \\
\hline college graduate & 0.066 & 0.080 & 0.409 & 0.198 & 0.091 & 0.030 \\
\hline accessed credit & 0.780 & 0.078 & $<0.001$ & -0.244 & 0.076 & 0.001 \\
\hline \multicolumn{7}{|l|}{ firm scale (ref: $0-9$ empl.) } \\
\hline 10-99 employees & 1.863 & 0.109 & $<0.001$ & -0.103 & 0.120 & 0.391 \\
\hline 100+ employees & 2.536 & 0.282 & $<0.001$ & 0.075 & 0.269 & 0.780 \\
\hline \multicolumn{7}{|l|}{ interactions } \\
\hline year $\mathrm{x}$ college graduate & 0.014 & 0.004 & $<0.001$ & 0.003 & 0.005 & 0.549 \\
\hline year $\mathrm{x}$ accessed credit & 0.013 & 0.004 & 0.001 & -0.002 & 0.004 & 0.617 \\
\hline year $x$ firm of 10-99 empl. & 0.016 & 0.006 & 0.008 & -0.007 & 0.006 & 0.243 \\
\hline year $x$ firm of $100+$ empl. & 0.019 & 0.014 & 0.175 & -0.004 & 0.012 & 0.739 \\
\hline
\end{tabular}

Notes: Parameter estimates and standard errors are combined estimates from 5 imputations. Within each imputation, standard errors are computed using bootstrap replicate weights for complex survey designs. 